\title{
Application of laboratory methods for understanding fish responses to black soldier fly (Hermetia illucens) based diets
}

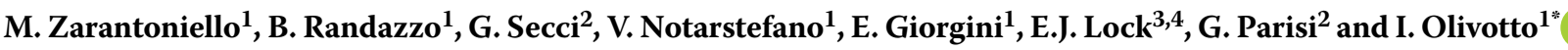 \\ ${ }^{1}$ Dipartimento di Scienze della Vita e dell'Ambiente, Università Politecnica delle Marche, via Brecce Bianche, 60131 Ancona, \\ Italy; ${ }^{2}$ Dipartimento di Scienze e Tecnologie Agrarie, Alimentari, Ambientali e Forestali (DAGRI), Università degli Studi di \\ Firenze, via delle Cascine 5, 50144 Firenze, Italy; ${ }^{3}$ Institute of Marine Research (IMR), 5817 Bergen, Norway; ${ }^{4}$ University \\ of Bergen, Department of Biological Sciences, P.O. Box 7803, 5020 Bergen, Norway; i.olivotto@univpm.it
}

Received: 29 October 2020 / Accepted: 20 January 2021

(c) 2021 Wageningen Academic Publishers

OPEN ACCESS CC) (i) (9)

REVIEW ARTICLE

\begin{abstract}
A major challenge for development of sustainable aquafeeds is its dependence on fish meal and fish oil. Replacement with more sustainable, nutritious and safe ingredients is now a priority. Over the last years, among several alternatives proposed, insects have received great attention as possible candidates. In particular, the black soldier fly (Hermetia illucens; BSF) represents a concrete example of how the circular economy concept can be applied to fish culture, providing a valuable biomass rich in fat and protein valorising organic by-products. In the last decade, several studies have been published about the use of different BSF dietary inclusion levels for various fish species including experimental models. Varying and encouraging results have been obtained in this research field using a plethora of laboratory methodological approaches that can be applied and coupled to obtain a comprehensive view of the BSF-based diets effects on fish physiology, health, and quality. The present review aims to explore some of the most promising laboratory approaches like histology, infrared spectroscopy, gut microbiome sequencing, molecular biology, fish fillets' physico-chemical and sensory properties, essential for a better understanding of fish welfare and fillet quality, when BSF is used as aquafeed ingredient. In particular, great importance has been given to European finfish species and experimental models.
\end{abstract}

Keywords: insect meal, alternative proteins, fish welfare, circular economy, sustainable aquaculture

\section{Introduction}

Due to the global capture fisheries stagnation, aquaculture is presently the fastest growing food production sector worldwide (FAO, 2018). Over the last years, there has been a significant increase in worldwide consumption of aquatic products (FAO, 2016) which is expected to further expand over the next thirty years (Gutiérrez et al., 2020). In this context, the aquaculture industry will face an important challenge: providing a world population estimated to reach 9.7 billion by 2050 with a proper amount of nutritious and safe aquatic food (FAO, 2016; Godfray et al., 2010). In order to meet this challenge, aquaculture production has to grow further (FAO, 2018). Although there is a high market demand for fish, a further development of aquaculture poses serious environmental challenges. As a result of ecological impacts of aquaculture inputs and resources, including water, land and feed, the sustainability in aquaculture is often restricted by a wide range of environmental concerns (Ahmed and Thompson, 2019; Naylor et al., 2005). Today, sustainable aquaculture technology and know-how have significantly advanced and they can play a pivotal role in achieving environmental sustainability goals. Longterm growth of the aquaculture industry has to be based on the concept of environmentally friendly practices and sustainable resource management. Presently, after the launch of Horizon 2020 by the European Community, aquaculture priorities can be summarised in three keywords: safe, sustainable, responsible. These words represent the basis for better animal's welfare, less environmental impact, and the development of new approaches able to provide larger volumes of healthy and safe food. 
Aquaculture feed accounts for $50-70 \%$ of production costs (Van Huis et al., 2013) and represent an equal share of the $\mathrm{CO}_{2}$ footprint (Winther et al., 2020). Because of the over-exploitation of pelagic fisheries, strategies to replace fish meal (FM) and fish oil (FO) in aquafeeds became both a private and public priority (Tacon and Metian, 2015). The study for low cost and sustainable feeding alternatives to totally or partially replace FM and FO have gained relevance (Henry et al., 2015; Voorhees et al., 2019) and to help the aquaculture industry to expand and remain competitive. Alternative ingredients are, for example vegetable proteins, including oilseeds (especially soybeans), and meat by-products (such as blood meal and bone meal). Among others, plant meals (PM) are the most widely used alternatives to FM since 2006 (Gatlin et al., 2007; Gerile and Pirhonen, 2017; Hardy, 2010). However, PM have unbalanced essential amino acids profile (due to the deficiency in methionine and lysine), low protein content, anti-nutritional factors and a significant amount of non-digestible carbohydrates, which often limit their use for carnivorous fish (Basto-Silva et al., 2019; Yasothai, 2016). In particular, non-digestible carbohydrates, including non-starch polysaccharides, may bind to bile acids or obstruct the action of digestive enzymes as well as feed transit in the intestine reducing both nutrients digestibility and absorption (Francis et al., 2001). In addition, PM can cause inflammation of the digestive tract of fish (Blaufuss et al., 2020; Henry et al., 2015) but also show low palatability (Henry et al., 2015; Papatryphon and Soares, 2001). Over the years, several techniques have been developed to partially overcome these issues including the use of enzymes, heat processes and the inclusion of bioactive compounds in the formulated diets (Gatlin et al., 2007; Oliva-Teles et al., 2015). In recent years, PM registered a significant rise in prices because of its increased use in human nutrition, causing a competition between the animal feed and human food sectors (Nogales-Mérida et al., 2018). As a consequence, PM industry has limited potential to expand its production without putting additional pressure on arable land use and water consumption and shifting resource demand from oceans to land (Hua et al., 2019).

Another alternative ingredient to FM in aquaculture is animal by-product meal (ABP). These meals contain a good balance of essential amino acids, show high protein content and good digestibility with features similar to those of FM (Barreto-Curiel et al., 2016; EL-Haroun et al., 2009; Hatlen et al., 2015). Although the ABP seems to be a good and viable alternative, at technical and economic level, the consumer acceptance, a strict regulation and many restrictions for their use due to a lack of knowledge on the risk for developing human diseases are its main limitation (European Commission, 2013). In the European Union, the use of ABP was prohibited from 1990 to 2000 due to the arising of the bovine spongiform encephalopathy in ruminants and then, in 2013, was allowed only for
ABP derived from non-ruminant animals (Category 3) (Moutinho et al., 2017). European legislation states that Category $3 \mathrm{ABP}$ can be processed for feeding aquatic animals to contribute responsibly to both environment and public health (Gasco et al., 2020).

Recently, the circular economy concept has gained great attention within the European Community and the EC Directive No. 2008/98 (EC, 2008), which establishes the order of importance in the choice of by-products treatment (the first being their recycle and the last being their landfill disposal) is playing a key role.

In order to meet the circular economy concept, aquafeed production can take advantage of the great amount of organic by-products which can be converted in a valuable biomass rich in proteins and lipids, by using bio-converting organisms (Lopes et al., 2020; Parodi et al., 2020; Truzzi et al., 2020; Zarantoniello et al., 2020b). Specifically, bioconversion through insects grown on organic byproducts as feed source might represent a valuable solution (Barroso et al., 2014; Belghit et al., 2019a; Henry et al., 2015). It also represents a valid example of sustainable animal production in terms of land use, water consumption and $\mathrm{CO}_{2}$ production, because of the low energy requirements during rearing procedures (Berggren et al., 2019; Smetana et al., 2019). The nutritional values of the insects' biomass are generally characterised by high fat and protein content (Barroso et al., 2014; Giannetto et al., 2020); however, the insects' biomass nutritional composition depends on the quality and quantity of feed offered for their growth (Gobbi et al., 2013; Pimentel et al., 2017; Truzzi et al., 2020; Zarantoniello et al., 2020b), with the fat content and quality varying the most (from 7 to $39 \%$ dry matter) (BarraganFonseca et al., 2017; Truzzi et al., 2020).

Among the insects species used for aquafeed production, Hermetia illucens (L.) (Diptera, Stratiomydae) (black soldier fly; BSF) is one of the most promising species: it shows high efficiency as bio-converter of organic by-product during the larval development (Salomone et al., 2017), a proper protein content (up to $60 \%$ dry weight) and an essential amino acid pattern similar to that of FM (Müller et al., 2017; Spranghers et al., 2017). Furthermore, BSF larvae represent a good source of lipids usually dominated by saturated fatty acids (SFA) (especially rich in lauric acid, 12:0), a medium chain fatty acid which has anti-inflammatory and immuneboosting properties (Gasco et al., 2018; Sealey et al., 2011). Their high content in SFA rather than in polyunsaturated fatty acid (PUFA) still represent a key-issue to be solved since this unbalanced fatty acid (FA) profile could impair fish growth, welfare and quality (Ewald et al., 2020).

Recently, methods to modulate the final biomass' nutritional profile by enriching the growing substrate have been developed (Liland et al., 2017; St-Hilaire et al., 2007). In 
particular, Truzzi et al. (2020) demonstrated that growing BSF prepupae on a rearing substrate enriched with $10 \%$ Schizochytrium sp. can improve insect's final biomass, especially in terms of some FA like PUFA.

The inclusion of new ingredients in aquafeeds must be approached cautiously, since it is well-known that modulatory effects of different feed ingredients on fish physiological responses, quality and safety exist (Li et al., 2019; Rimoldi et al., 2019). The scientific community should take into consideration productivity, fish welfare and endproduct's quality in order to guarantee both animals and humans wellbeing.

While productivity is not affected by proper insect meal inclusion levels in aquafeeds (Belforti et al., 2015), the main problem found in the use of insect meal in fish production is changes in the FA profile of the fish product (Ferrer Llagostera et al., 2019). When fed on insect meal based diets, fish fillets generally showed a reduced n-3/n-6 ratio, as well as low PUFA content, reducing the nutritional quality of fish for human consumption (Devic et al., 2018; Ruxton et al., 2004). In addition, since a large variety of organic by-products can be used as feed for insects, potentially toxic elements and pathogen microorganisms can enter the food production chain and be potentially harmful to animals and humans (Bosch et al., 2019; Swinscoe et al., 2019). Therefore, to meet a safe production of insects, a strict chemical and microbiological monitoring is necessary.

During the last decade, the issue of farmed fish welfare has raised increasing public and scientific concern (Panagiotaki and Malandrakis, 2019). Animal welfare has been defined as 'the aptitude of an animal to familiarise to its environment and maintain good health, while living a natural life and show its natural behaviour' (Ashley, 2007; Brijs et al., 2018). Much research on the welfare of farmed fish is thus required to provide recommendations for best practices and future legislation (Ashley, 2007; EFSA, 2009). Farmed fish are usually exposed to a variety of stressors including handling, stocking density and nutrition which long-term exposure could have negative effects on health and growth performances (Barton, 2002; Olivotto et al., 2002; Piccinetti et al., 2015; Tocher, 2010). When it comes to new feed ingredients the gastrointestinal tract plays a key role. It constitutes an important barrier to the external environment (Groschwitz and Hogan, 2009), providing defence against pathogens and tolerance to dietary antigens (Peterson and Artis, 2014) while playing, at the same time, a fundamental role in the absorption of nutrients (Uran et al., 2008) and on the innate and adaptive immunity of fish (Donaldson et al., 2015; Kinnebrew and Pamer, 2012). Therefore, intestine integrity is considered to be essential to sustain a proper fish growth and welfare.
Presently, the fast development of science and the development of several new laboratory techniques allow scientist to have a deep and comprehensive approach when studying the effects of new practical diets in aquaculture. Numerous laboratory techniques like histology, infrared spectroscopy, gut microbiome sequencing, molecular biology as well as fish fillets' physico-chemical and sensory properties are now available for a better understanding of the above-mentioned aspects related to fish farming, representing an up-to date approach for a better understanding of the effects of insect-based diets on fish welfare and production.

The present review aims to provide an overview on the main analytical methods presently available for understanding welfare and quality of fish when fed on diets including BSF meal. Emphasis is given to a number of fish species of interest for the European aquaculture as well as to experimental models.

\section{Fish gut and liver}

\section{Histology}

Novel feed formulations for fish need to evaluate not only economical cost/benefit but also the effect on fish welfare. The gastrointestinal system is the primary target of dietary changes and challenges (Giorgini et al., 2018a).

Histological analysis of the digestive apparatus is considered one the main approaches to evaluate fish welfare and nutritional status (Raskovic et al., 2011). In particular, intestine and liver are the most important organs involved in digestive and immune functions and, consequently, are of particular interest when new ingredients are applied to aquafeed formulation (Ray and Ringø, 2014; Robaina et al., 1995; Zhang et al., 2020).Intestinal morphology is considered one of the main indicators of fish health since its morphological structure rapidly and often reversibly changes in response to dietary inputs. Alteration of gut integrity may modify nutrient absorption and thus fish welfare and growth, possibly affecting productivity (Krogdahl et al., 2015, 2010; Penn et al., 2011; Santigosa et al., 2011; Voorhees et al., 2019; Zhang et al., 2013). Morphometric assessment of intestine architecture is widely used for studying intestine response to dietary challenges and involves the measurement of a number of histopathological parameters, in fish species (Baeverfjord and Krogdahl, 1996; Daprà et al., 2011; Gu and Li, 2004; Krogdahl et al., 2003; Swatson et al., 2002).

Histological analysis relies on the use of tissue staining techniques to visualise intestinal morphology and specific cell markers. Among the most widely used stainings, haematoxylin and eosin staining (H\&E) is commonly applied to provide general morphological information and 
to detect and discriminate inflammatory cells (lymphocytes, granulocytes, melanomacrophages, etc.) (Mokhtar, 2017) based on their acidophilic (eosin) or basophilic (haematoxylin) features.

Other stainings allow to obtain more accurate information about the chemical composition of some cell categories, by virtue of specific chemical reactions (Dama and Pathan, 2019). As for example, periodic-acid Schiff (PAS) staining and Alcian blue $\mathrm{pH} 2(\mathrm{AB})$ staining are elective for neutral and acid (PAS and $A B$, respectively) mucins in mucous cells (Cardoso et al., 2015; Purushothaman et al., 2016).

The analysis of mucous cells in the intestinal epithelial layer is also of particular interest (Cardinaletti et al., 2019; Zarantoniello et al., 2021). These cells are able to produce and release defensive substances including mucins, lectins, toxins, immunoglobulins and antimicrobial peptides in response to specific dietary stimuli or mechanical injury (Bosi et al., 2017; Hasnain et al., 2013; Lazado and Caipang, 2014).

Aside providing information on the cell type and tissue morphology, histological analysis can be useful to obtain a number of histopathological parameters able to provide (semi-) quantitative information on possible intestinal alterations through a multi-grade scoring system (Silva et al., 2015).

The most traditional histopathological indexes include: mucosal folds morphology (length, width, fusion), enterocytes supranuclear vacuolisation, lamina propria and submucosa width, leucocyte infiltration (also named 'cellularity'), and mucous cells abundance (Baeverfjord and Krogdahl, 1996; Knudsen et al., 2008; Laporte and Trushenski, 2012; Morris et al., 2005; Penn et al., 2011; Uran et al., 2008). Since insect meal is known to include different molecules like chitin and short-medium FA, which may have an important role in gut welfare regulation (Bruni et al., 2018; Gasco et al., 2018; Rimoldi et al., 2019), the analysis of all these parameters has recently been applied to several studies in order to provide information on possible inflammation and/or alterations in the nutrient transport in fish (Li et al., 2020b).

Most of the histological studies have been performed on Atlantic salmon (Salmo salar) (Li et al., 2019; Lock et al., 2016), rainbow trout (Oncorhynchus mykiss) (Cardinaletti et al., 2019; Renna et al., 2017) and zebrafish (Danio rerio) (Zarantoniello et al., 2019, 2020b), while a few studies are available on Siberian sturgeon (Acipenser baerii) (Caimi et al., 2020a,b; Józefiak et al., 2019b; Zarantoniello et al., 2021) and Japanese sea bass (Labrax japonicas) (Wang et al., 2019).

As regards Atlantic salmon, studies which adopted histological analyses in support to other laboratory techniques, showed that a partial (40\%) up to a total substitution of FM with full-fat (Lock et al., 2016) or partially defatted (Li et al., 2020b) BSF prepupae meal did not cause negative effects on post-smolt Atlantic salmon intestine morphology, indicating a high tolerance of salmonids to high dietary BSF meal inclusion levels.

The inclusion of a full-fat BSF prepupae meal in pre-smolt Atlantic salmon diet showed beneficial effects on fish intestine by reducing the enterocyte hyper-vacuolisation which usually characterises intestine of fish fed diets including high levels of soybean meal (Heikkinen et al., 2006; Li et al., 2019) and decreased steatosis in proximal intestine (Li et al., 2020b).

Moreover, studies performed on rainbow trout showed that up to a $50 \%$ dietary substitution of FM with partially defatted (Dumas et al., 2018; Renna et al., 2017) BSF prepupae meal did not affect anterior or distal intestinal tracts morphology. However, Józefiak et al. (2019a) showed a slight decrease of villi height in trout proximal intestine fed a $50 \%$ dietary full-fat BSF inclusion level with respect to FM. In another recent study performed on rainbow trout fed diets containing 25 or $50 \%$ full-fat BSF meal with respect to FM (Cardinaletti et al., 2019), no intestine severe inflammatory events were highlighted but a significant mucosal folds height reduction was observed in both groups, respected to control. In addition, Randazzo et al. (2020b, 2021b) showed a dose dependent increase of distal intestine mucous cells in rainbow trout fed diets in which 30 or $60 \%$ of vegetable proteins were replaced with defatted BSF prepupae meal. This result suggests a possible involvement of undigested chitin in inducing a higher lubrication of the intestine final tract. Similarly, it was demonstrated that dietary administration of fullfat BSF prepupae meal ( 25 or $50 \%$ with respect of FM) stimulated a higher secretion of neutral mucins rather than the acidic ones, along the entire digestive tract of rainbow trout (Cardinaletti et al., 2019). These results suggest a possible involvement of undigested chitin in inducing a higher lubrication of the intestine final tract. Differently, Elia et al.(2018) did not evidence significant differences in mucous cells (both rich in neutral and acidic mucins) in rainbow trout, independently of partially defatted BSF larvae meal dietary inclusion ( 25 or $50 \%$ ). However, the role of chitin in inducing mucous cells proliferation has still not been directly demonstrated and further studies are necessary.

To date, no studies are available on the effects of BSF meal dietary inclusion on European sea bass (Dicentrarchus labrax) intestinal histology, while one has recently been published on gilthead seabream (Sparus aurata) by Randazzo et al. (2021a). In addition, a recent study on Japanese sea bass showed that a replacement up to $64 \%$ of FM by defatted BSF meal did not affect intestine integrity (Wang et al., 2019). 
Only recently, a few studies focused on the effects of BSF prepupae meal dietary inclusion on Siberian sturgeon gut morphology: Józefiak et al. (2019b) showed that a diet in which $15 \%$ of FM was replaced by full-fat BSF meal caused a reduction in intestinal muscular and mucosal thickness but did not affect mucosal folds length, while Caimi et al. (2020a) did not report histological alterations of the distal intestine in fish fed highly defatted BSF meal ( 25 or $50 \%$ replacement with respect to FM).

Conversely, Zarantoniello et al. (2021), in juvenile sturgeons, demonstrated that a $50 \%$ dietary inclusion level of full-fat BSF meal with respect to FM induced mucosal folds atrophy and a dramatic decrease of enterocyte vacuolisation.

Recently, the effects of the administration of BSF-based diets in the experimental model zebrafish were deeply investigated. Particularly, a general increase in mucous cells number was observed in zebrafish larvae fed exclusively on full-fat BSF prepupae meal (Vargas et al., 2018). On the contrary studies in which zebrafish were fed on diets including increasing inclusion levels of full-fat BSF prepupae meal (with respect to FM) did not show intestine morphology changes (Zarantoniello et al., 2019, 2020a,b).

In addition to intestine, liver is often considered a second target organ when testing new aquafeed ingredients. This is particularly important when testing insect meal since its FA composition, rich in SFA, may alter the lipid accumulation in this organ (Vargas-Abúndez et al., 2019). Liver welfare is a key aspect for fish production since this organ plays a central role in many of the fish metabolic pathways and its morphological structure and macromolecular composition are deeply influenced by the diet (Bruni et al., 2020b; Cardinaletti et al., 2019; Novriadi et al., 2018; Vargas-Abúndez et al., 2019).

Several histological analyses, using the above-mentioned histological stainings, may be applied to the liver, providing information about lipid accumulation, inflammation, necrosis, and glycogen deposition in this organ.

In 1997, McFadzen et al. (1997) proposed a criteria scale for the analysis of fish liver in order to determine the nutritional conditions and this approach has been successfully applied over the years for studying the effects of dietary challenges on farmed fish species (Sabbagh et al., 2019). Liver histological parameters are responsive to food quality and availability (O'Connell, 1976) and are particularly addressed to provide information on hepatocyte morphology, with emphasis on the relative amount of intracellular vacuolisation associated with lipid and glycogen storage.

The fatty acid profile of insects does not always match the nutritional requirements of fish since insects are rich in medium-chain SFA and MUFA rather than in long-chain PUFA. Liver lipid and glycogen deposition can provide important information on the effects and suitability of BSF-based diets (Bruni et al., 2020b; Cardinaletti et al., 2019; Li et al., 2016). While traditional staining (H\&E) allows to detect hepatocytes lipid storage, histochemical PAS staining helps in detecting liver glycogen accumulation (Aziza et al., 2013; Bui-Nguyen et al., 2015).

In post-smolt Atlantic salmon fed full-fat BSF prepupae meal diets (from 33 up to $100 \%$ with respect to FM), a dose-dependent increase in liver lipid accumulation was observed (Belghit et al., 2019a), while only minor effects on liver lipid deposition were observed in Japanese sea bass fed diets including defatted BSF prepupae meal (Wang et al., 2019). Similarly, an increase in liver lipid deposition was evidenced in rainbow trout fed diets containing 25 or $50 \%$ full-fat BSF meal with respect to FM (Bruni et al., 2020b; Cardinaletti et al., 2019).

Studies performed on zebrafish suggested that the $\mathrm{n}-6 / \mathrm{n}-3$ ratio is a key factor in determining hepatic lipid accumulation. The higher the ratio value, the higher was the hepatic lipid accumulation (Vargas et al., 2018; Zarantoniello et al., 2018, 2019, 2020b). Finally, Li et al. (2017) evidenced a reduction in liver lipid deposition in the herbivorous species Jian carp fed on defatted BSFbased diets.

With respect to glycogen deposition, to date, only a few studies applying a histological approach are available. PAS was used to discriminate the contribution of glycogen in hepatocytes composition of juvenile clownfish (Amphiprion ocellaris) fed partially defatted BSF larvae meal (25, 50 or $75 \%$ replacement with respect to FM) and rainbow trout fed full-fat BSF prepupae meal ( 25 or $50 \%$ with respect of FM). However, no significant differences among the experimental groups were detected in terms of glycogen accumulation (Cardinaletti et al., 2019; Vargas-Abúndez et al., 2019).

From this overview it is clear that fish responses are not only species-specific but also dependent on fish life stage and on the characteristics of BSF meal (full-fat or defatted). A traditional and well-established method like histology plays a pivotal role in the analysis of fish gut and is still used as gold standard serving scientific research because of its validity and accuracy. These types of analysis could provide the community with essential insights on the effects of BSF meal on fish.

\section{Fourier transform infrared spectroscopy: hyperspectral imaging analysis and biomolecular composition}

Fourier Transform Infrared (FTIR) spectroscopy is a well assessed analytical tool for the analysis of biological samples, such as tissues, cells and biological fluids 
(Giorgini et al., 2018b; Notarstefano et al., 2019, 2020). The interaction between the electromagnetic radiation in the mid-infrared spectral range $\left(4,000-800 \mathrm{~cm}^{-1}\right)$ and the samples causes vibrational transitions at the level of chemical bonds, allowing to identify the presence of specific chemical groups (Talari et al., 2017). This potentiality coupled with the optical microscopy allows to perform the hyperspectral imaging analysis of selected areas inside the analysed samples. In addition, this tool lets combine the topographical distribution of the most relevant biomolecules (in terms of lipids, proteins, carbohydrates and nucleic acids) with meaningful information on the biochemical composition and the occurrence of specific biological mechanisms and pathways (Giorgini et al., 2018a; Randazzo et al., 2020a; Zarantoniello et al., 2020a).

FTIR spectroscopy has recently been applied to evaluate the physiological responses of fish species to BSF-based diets, including rainbow trout, Siberian sturgeon, and zebrafish. Most of the studies applying this specific technique have been performed on zebrafish, where administration of diets with increasing full-fat BSF meal levels $(0,25,50,75$ or $100 \%$ with respect to FM; Hi0, Hi25, Hi50, Hi75 and Hi100 fish groups, respectively) was tested during the larval, juvenile and adult phases.

As regards the zebrafish larval phase, due to the small sample size, FTIR analysis was performed on lyophilised samples. Statistically significant higher amounts of overall lipids and SFA were found in Hi50, Hi75 and Hi100 groups with respect to control $(\mathrm{HiO})$ and $\mathrm{Hi} 25$, together with a decrease of the unsaturated FA; conversely, no statistically significant changes were detected in terms of protein composition (Zarantoniello et al., 2020b).

In juvenile and adult zebrafish, cryosections (10 $\mu \mathrm{m}$ thick) of specific target organs (such as liver and ovaries) were analysed. In liver, the hyperspectral imaging analysis provided details on the biochemical composition of this organ which were subsequently coupled to the histological data to provide a more comprehensive overview (Zarantoniello et al., 2019, 2020a). As an example, liver samples of juvenile zebrafish fed diets including increasing BSF meal levels $(0,25,50,75$ or $100 \%$ with respect to FM; $\mathrm{Hi}$, Hi25, Hi50, Hi75 and Hi100 groups, respectively) showed an increment of total FA together with a decrease of both carbohydrates and phosphates. Specifically, in Hi75 and Hi100 liver samples, higher amounts of total lipids and lower ones of proteins were detected, while the lowest glycogen levels were found in $\mathrm{Hi} 50$ and $\mathrm{Hi} 75$ groups (Zarantoniello et al., 2020a).

Recently FTIR was used to characterise the macromolecular composition of class IV oocytes of zebrafish adult females fed over a 12 months period on BSF-based diets (Randazzo et al., 2020a). Specifically, while similar amounts of SFA,
MUFA and PUFA were found in control and Hi25 groups, Hi50 showed higher SFA and lower PUFA contents. This study suggested that the substitution of FM with BSF meal up to $25 \%$ in zebrafish female diet did not affect reproductive performance, while a higher inclusion $(50 \%$ with respect to FM) resulted in reproductive impairments, specifically in terms of number of spawned eggs.

Since high dietary SFA and n-6 PUFA intake have often been related to behavioural and cognitive impairments in humans and rodents, FTIR was also applied to better understand the FA composition of zebrafish brain in response to dietary BSF meal inclusion. Although specific behavioural tests such as open-field and photic entrainment tests did not evidence differences among the experimental groups, the FTIR analysis highlighted that increasing dietary full-fat BSF meal inclusion levels caused a drastic decrease of unsaturated FA and carbohydrates in zebrafish brain samples. These results suggest possible compensatory pathways developed by the fish (Zarantoniello et al., 2020a).

For commercially relevant species, only a few studies that applied FTIR technique are available. Recently, Giorgini et al. (2018a) analysed by FTIR spectroscopy cryosection of medium and hind intestinal tracts of rainbow trout, with emphasis on the mucosa layer. The spectral outcomes were compared to those obtained through the classical histological analysis, based on three different staining methods. The hyperspectral imaging analysis confirmed that the distribution of the most represented macromolecules followed the well-known arrangement of intestine tissues. In addition, the hyperspectral imaging provided a proper outline on the macromolecular composition and the building blocks of rainbow trout intestinal mucosa, through a semi-quantitative information obtained by univariate analysis of the spectral data.

Moreover, the effects of practical diets with increasing full-fat BSF meal levels (0, 25 and 50\% with respect to FM) on the macromolecular composition of rainbow trout juvenile's liver have been investigated (Cardinaletti et al., 2019). Results showed that liver samples from fish fed diet with 50\% BSF meal inclusion level (with respect to FM) contained higher amounts of lipids and glycogen compared to a control group.

Finally, FTIR was used to assess the liver macromolecular composition and small intestine nutrient absorption in Siberian surgeon fed diets in which $50 \%$ of dietary FM was replaced by full-fat BSF prepupae meal (Zarantoniello et al.,2021). As regards liver, a significant decrease of total lipids, FA and glycogen was observed compared to the control group fed a FM control diet. Conversely, no change was observed in the macromolecular composition of small intestine samples. 
Based on these results, FTIR spectroscopy represents a reliable tool for the analysis of different fish organs and tissues, providing at the same a correlation between chemical and morphological features and, as further extent, improving histological outcomes.

\section{Microbiome}

Dietary composition is one of the key factor in shaping fish gut microbial communities (Egerton et al., 2018; Wang et al., 2018) which in turn can modulate fish metabolism, intestinal mucosa development and maturation, immunity and disease resistance (Llewellyn et al., 2014; Maslowski and MacKay, 2011).

The use of BSF prepupae meal as aquafeed ingredient has been shown to positively affect fish intestinal microbiota biodiversity, regardless of the insects' life-cycle stage and/ or defatting process, the insects' dietary percentage of inclusion or the fish species analysed (Huyben et al., 2019; Józefiak et al., 2019a,b; Li et al., 2020a; Rimoldi et al., 2019). Presently, most of the studies on the effects of BSF-based diets on the microbiome have been performed on rainbow trout (Bruni et al., 2018; Huyben et al., 2019; Józefiak et al., 2019a; Rimoldi et al., 2019; Terova et al., 2019).

Bruni et al. (2018) explored the effects of 25 or $50 \%$ of FM replacement with partially defatted BSF prepupae meal in rainbow trout using the denaturing gradient gel electrophoresis (DGGE), highlighting an increase in intestinal bacterial diversity in fish fed BSF-based diets. DGGE is a well-established, reproducible, rapid and less expensive molecular tool based on genetic fingerprinting. DNA or RNA extraction is followed by the amplification of genes encoding the 16s rRNA and then by the analyses of amplification products by a denaturing gradient gel electrophoresis. In addition, the identification of community members is made possible by the sequencing of excised bands or by hybridisation analyses by specific probes (Muyzer, 1999; Osimani et al., 2019).

An increased biodiversity was reported also by Józefiak et al. (2019a), through the fluorescent in situ hybridisation, including $20 \%$ of full-fat BSF prepupae in rainbow trout diet. This hybridisation technique based on nucleic acids allows the identification of microbial species using group or species-specific fluorescent labelled oligoprobes avoiding the use of DNA extraction and polymerase chain reaction (PCR) (Kumar et al., 2018).

These results were in line with further studies performed on rainbow trout (Huyben et al., 2019; Rimoldi et al., 2019; Terova et al., 2019) that evidenced an increased microbiome biodiversity with dietary administration of up to $30 \%$ of defatted BSF prepupae meal, using high throughput sequencing method (Illumina MiSeq). This next-generation sequencing tool allows to inexpensively produce large volumes of sequence data and to have a higher power of resolution in detecting microbial species compared to conventional methods (McAdam et al., 2014; Metzker, 2010). Illumina sequencing was also utilised in studies performed on Atlantic salmon (Li et al., 2020a) and Siberian sturgeon (Zarantoniello et al., 2021) that, in agreement with the previous studies, highlighted an increase in microbial community diversity in fish fed diets including $15 \%$ of partially defatted BSF larvae meal or $50 \%$ of full-fat BSF prepupae meal, respectively.

A higher microbiome diversity is generally considered as an indicator of improved gut health, while a reduced diversity has frequently been associated to gastrointestinal tract colonisation by pathogens (Apper et al., 2016; Sekirov et al., 2010).

The overall increased diversity and the positive modulation of intestinal microbial communities in response to different levels of dietary BSF meal inclusions have been mainly attributed to chitin. Chitin is generally considered not easily digestible by fish but represents one of the main growth substrates of lactic acid bacteria (LAB) (Askarian et al., 2012; Ringø et al., 2012). LAB are related to Firmicutes and Actinobacteria phyla which usually represent the 'core gut microbiota' in different marine and freshwater species (Ghanbari et al., 2015; Givens et al., 2015; Li et al., 2014; Ringø et al., 2016; Wong et al., 2013). These bacteria, using chitin as prebiotic, are crucial in making available indigestible carbohydrates leading to a better nutrient accessibility and utilisation for fish (Beier and Bertilsson, 2013). In addition, LAB contribute to the synthesis of vitamins and short-chain FA, considered as the primary enterocyte's energy source (Ghanbari et al., 2015), or of important anti-inflammatory molecules, like butyrate (Rimoldi et al., 2016; Terova et al., 2016).

Firmicutes and Actinobacteria phyla have been shown to increase in intestinal mucosa and digesta of rainbow trout fed with defatted BSF prepupae meal (up to $50 \%$ of inclusion; Bruni et al., 2018; Rimoldi et al., 2019; Terova et al., 2019) or full-fat BSF prepupae and larvae meal (30\% of inclusion; Huyben et al., 2019). In particular, Terova et al. (2019) reported that the dietary defatted BSF inclusion increased the relative abundance of Lactobacillales, mainly represented by Lactobacillaceae and Leuconostocaceae, involved in starch and fibres digestion as well as of bacteria from the order Clostridiales that includes many butyrate producers like Clostridium butyricum.

Similarly, an enhanced colonisation of Lactobacillus sp. was observed in rainbow trout fed a diet including 20\% of full-fat BSF prepupae meal (Józefiak et al., 2019a) and in Siberian sturgeon fed 15\% of full-fat BSF larvae meal (Józefiak et al., 2019b). 
As reported by Huyben et al. (2019), the abundance of Bacillaceae (phylum Firmicutes) was higher in rainbow trout fed BSF-based diets and this increase was attributed to the high level of dietary chitin since these bacteria are able to use chitin through the endogenous production of chitinase. Furthermore, the same authors demonstrated that the presence of Corynebacterium (phylum Actinobacteria) was higher in rainbow trout fed the full-fat BSF larvae or prepupae meal with respect to the defatted larvae meal. This underlies the ability of Corynebacterium to use dietary lipid through the activation of endogenous lipases (Brennan et al., 2002). An increased abundance of Corynebacterium was also observed in Atlantic salmon fed on partially defatted BSF-based diet (15\% of inclusion) with respect to the control diet (Li et al., 2020a).

Furthermore, chitin and its deacetylate derivate chitosan have antimicrobial properties and bacteriostatic effects, particularly on some Gram-negative pathogen bacteria (Nawaz et al., 2018; Qin et al., 2014; Udayangani et al., 2017). This defence mechanism could be enhanced by $\mathrm{LAB}$ which are able to produce bactericidal compounds like lactic acid, hydrogen peroxide and biosurfactants preventing the adhesion to intestinal mucosa of pathogens like Staphylococcus aureus, Streptococcus agalactiae and Pseudomonas aeruginosa (Gajardo et al., 2017; Gudiña et al., 2015).

Several studies on rainbow trout fed defatted BSF prepupae meal diets (up to $50 \%$ of inclusion; Bruni et al., 2018; Rimoldi et al., 2019; Terova et al., 2019) or full-fat BSF prepupae and larvae meal diets (30\% of inclusion; Huyben et al., 2019) revealed a reduction in both gut digesta and mucosal-adhered Proteobacteria, a Gram-negative phylum containing pathogens. In particular, Rimoldi et al. (2019), reported that 20 or $30 \%$ of defatted BSF prepupae meal dietary inclusion increased the number of bacteria belonging to Mycoplasma genus which is associated to a beneficial effect on host health due to the production of lactic and acetic acids as main metabolites (Razin, 2006). Similarly, rainbow trout fed 25 or $50 \%$ of defatted BSF prepupae meal inclusion in diets were particularly rich in Pseudomonas stutzeri (Bruni et al., 2018) which possess antiviral activity and was listed as a probiotic bacterium (Balcázar et al., 2006; Nayak, 2010). In contrast, in rainbow trout, a 20\% full-fat BSF prepupae meal inclusion caused an increase in the Clostridium coccoides abundance (Józefiak et al., 2019a) which is known to play an important role in fish immune response and pathological processes (Liu et al., 2016).

Finally, recent studies performed on zebrafish fed diets with increasing inclusion levels of full-fat BSF prepupae $(0,25,50,75$ or $100 \%)$ showed contradictory results. In zebrafish larvae, the positive effects of dietary BSF inclusion was highlighted by the highest microbial community biodiversity showed by the group fed $50 \%$ substitution of FM with full-fat BSF prepupae meal as well as by the Vibrio abundance which was negatively influenced by the dietary increasing inclusion of full-fat prepupae meal (Zarantoniello et al., 2020b). Conversely, the same BSF dietary inclusion levels caused in zebrafish juveniles, a reduction of microbial diversity (Zarantoniello et al., 2020a). However, the overall fish gut health was preserved since BSF prepupae meal is particularly rich in lauric acid which is known to possess anti-inflammatory and antimicrobial properties against Gram-positive bacteria (Skřivanová et al., 2005, 2007; Spranghers et al., 2018).

It should be pointed out that to fully unveil the response of intestinal microbiota to BSF dietary inclusion levels, differences between mucosa-adhered and gut digesta communities must be considered since some allochthonous species could poorly colonise host intestine with a lower biodiversity with respect to the intestinal content (Kim et al., 2007). Different studies on BSF prepupae meal administration in salmonids reported that microbial diversity was higher in gut digesta than in intestinal mucosa (Bruni et al., 2018; Li et al., 2020a). For that reason, analysing only gut digesta- or intestinal mucosa- associated microbiota or a mixture of both of them could partially underestimate microbial community response to dietary changes, while it is recommended to profile mucosal and digesta communities separately when feasible.

\section{Molecular biology (real-time PCR): growth factors, immunity, chitinases, lipid metabolism, appetite stimulus}

One of the most robust and widely used methods for gene expression quantification is the real-time PCR which is able to distinguish and amplify a specific nucleic acid sequence in a sample, monitoring the amplification process through the correlation between product concentration and fluorescent intensity (Olivotto et al., 2011; Valasek and Repa, 2005; Wong and Medrano, 2005).

This technique has been used in some of the most important finfish species like gilthead sea bream (Psofakis et al., 2020), European sea bass (Kokou et al., 2019), Atlantic salmon (Belghit et al., 2019b), Siberian sturgeon (Luo et al., 2019), sole (Piccinetti et al., 2015), ballan wrasse (Piccinetti et al., 2017) and rainbow trout (Lindholm-Lehto et al., 2019). However, because of the lack of complete and easy genomic information availability about these last species its application is still limited (Ribas and Piferrer, 2014).

With the use of BSF meal in aquafeed formulation, studies about the application of real-time PCR over the last few years are quite limited and mainly focused on growth factors, fish immune and stress response, appetite stimulus, lipid metabolism and chitinolytic activity. 
Considering growth factors [insulin-like growth factors (igf1, igf $2 a$ ) and myostatin (mstn)], BSF meal dietary inclusions usually resulted in good growth performance in most of the studies. In both zebrafish larvae and in rainbow trout juveniles, an increase in growth parameters was well supported by the hepatic gene expression of the growth factors (Cardinaletti et al., 2019; Zarantoniello et al., 2020b). These results support the hypothesis that BSF meal possesses a proper amount of proteins (up to $60 \%$ dry weight) and a well-balanced amino acid (AA) profile (similar to that of FM) which are key dietary features to guarantee a proper aquaculture production (Barroso et al., 2014).

Fish growth is strictly related to feed intake and the brain (particularly the hypothalamus) is a key-actor in regulation of energy metabolism, nutrient absorption, and the control of feeding activity. However, it should be considered that the gastrointestinal tract is connected to the brain in metabolic and appetite control. The gut-brain crosstalk occurs through the release of a number of gut peptides that exert responses within the brain, as well as through neuroendocrine and sensory inputs from the gut (Sadoul and Vijayan, 2016). Other signals are also involved such as nutrient levels, through central nutrient sensing systems, and the presence/ absence of food in the gastrointestinal tract, through vagal afferents projecting to the brain (Bertucci et al., 2019). To date, studying the gene expression of both orexigenic [ghrelin ( $g h r l)$, neuropeptide y (npy) and cannabinoid receptor $1(c n r 1$ or $c b 1)$ ] and anorexigenic [leptin (lepa) and melanocortin 4 receptor $(m c 4 r)$ ] signals represents a valid tool to better understand fish responses to new formulated diets. No significant variation in $\mathrm{ghrl}$ gene expression in medium and distal intestine of rainbow trout juveniles fed with practical diets containing 30 or $60 \%$ substitution levels of vegetable proteins with BSF prepupae meal was recently evidenced (Randazzo et al., 2020b). However, in the same experimental group, but considering brain, appetite signals analysed (cb1, npy and mc4r) showed a significant downregulation (Randazzo et al., 2020b). Differently, in zebrafish larvae and juveniles, gene expression of orexigenic signals ( $g h r l, n p y$ and $c b 1$ analysed in whole fish samples for zebrafish larvae; $g h r l$ and $c b 1$ in intestine samples for zebrafish juveniles) increased with the increasing dietary BSF prepupae meal inclusion levels (Zarantoniello et al., 2020a,b) fully supporting growth.

While BSF meal has been proven to be an adequate protein source, its inclusion in aquafeeds is still possibly limited by the chitin content (Olsen et al., 2006; Spranghers et al., 2017) and its (often) unbalanced FA profile (Ewald et al., 2020).

Over the last years a controversial role has been attributed to chitin in aquafeed formulation (Henry et al., 2015). High dietary inclusion levels of BFS meal (and possibly of chitin) often induced a fish growth reduction (Caimi et al., 2020b; Zarantoniello et al., 2019, 2021); however, no direct correlation between chitin feed content and fish growth reduction has yet been demonstrated. Chitin can also have a beneficial activity on the fish immune system, lower stress response and improved gut health (Józefiak et al., 2019a; Nogales-Mérida et al., 2018; Ringø et al., 2012).

The use of molecular markers represents a valid and up to date tool since several biomarkers are available, for different fish species, to assess stress and immune response. Studies demonstrated the correlation between increased gene expression levels of glucocorticoid receptor and heat shock proteins and exposure to stressors (including malnutrition; Piccinetti et al., 2015). Pro-inflammatory cytokines such as interleukin 1-beta (il1b), tumour necrosis factor a (tnfa), anti-inflammatory cytokines like interleukin-10 (il10), and inflammation mediators such as nuclear factor kappa-lightchain-enhancer of activated B cells $(n f k b)$ and myeloid differentiation primary response 88 (myd88) represent useful markers of inflammation, able to provide early information when testing new ingredients in aquafeed formulation (Fehrmann-Cartes et al., 2019; Marjara et al., 2012; Seierstad et al., 2009). However, the presently available results are still controversial and fish responses seem to be species and stage specific as well as related to BSF meal dietary inclusion levels.

Gut gene expression of immune response markers in adult zebrafish (il1b, il6 and tnfa; Zarantoniello et al., 2019), presmolt (il4, tgfß1, il10, ifny, ils and myd88; Li et al., 2019) and seawater-phase (il1b, il17a, myd88, il8, il4, mhcl, il10, ifn $\gamma, \operatorname{tg} f \beta 1, c d 8 \beta, c d 3 \gamma \delta$ and foxp 3; Li et al., 2020b) Atlantic salmon was not negatively affected by the BSF-meal dietary inclusion level up to 50,60 or $100 \%$, respectively.

Conversely, a dietary full-fat BSF inclusion of $50 \%$ or higher resulted in the immune response activation in both larval and juvenile zebrafish intestine (il1b, il10, il6 and tnfa; Zarantoniello et al., 2018, 2020ab) and in rainbow trout juveniles medium intestine (il10, tnfo and tlr-5; Cardinaletti et al., 2019) as well as in the stimulation of regulatory $\mathrm{T}$ cell activity in the proximal and distal intestine of Atlantic salmon ( $c d 3 \gamma \delta$ and foxp3; Li et al., 2019).

Inflammatory events detected by real-time PCR can be coupled with a higher stress response: an increase in the hepatic $h s p 70.1$ gene expression was detected in rainbow trout juveniles (Cardinaletti et al., 2019) and pre-smolt Atlantic salmon (Li et al., 2019). Accordingly, in zebrafish larvae and juveniles, an increased dietary full-fat BSF prepupae meal inclusion resulted in a higher hepatic $h s p 70.1$ and glucocorticoid receptor $(n r 3 c 1)$ gene expression (Zarantoniello et al., 2020a,b). However, in Atlantic salmon fed diets with higher full-fat BSF meal inclusion ( $85 \%$ of the diet protein content) the hepatic expression of $h s p 70.1$ was not affected by the diet (Belghit et al., 2019b). 
Finally, due to the unbalanced fatty acid profile of BSF meal, with emphasis on their lack of PUFA, a number of biomarkers related to long-chain PUFA biosynthesis and FA metabolism is now available and represents a great opportunity for better understanding the biosynthetic pathways in different fish species in response to dietary treatments. Most of the studies so far published focused their attention on elongase and desaturase gene expression. Specifically, Bruni et al. (2020b) demonstrated that the elovl 2 and fads 2 gene expression in the pyloric caeca of rainbow trout juveniles tended to increase with the increasing amount of the dietary full-fat BSF meal inclusion (25 and 50\%). Accordingly, in both zebrafish larvae (Zarantoniello et al., 2020b) and adults (Randazzo et al., 2020a; Zarantoniello et al., 2019), an upregulation of elovl2, elovl5 and fads hepatic gene expression was observed in experimental groups fed the highest full-fat dietary BSF prepupae meal inclusion (100 and 50\%, respectively). The dietary lack of PUFA in freshwater fish fed BSF-based diets could enhance the conversion of shorter-chain FA in highly unsaturated ones through the activation of elongation and desaturation pathways (Tocher, 2010). Furthermore, an increasing expression of markers involved in FA ( $c d 36$, fabp2) and cholesterol (npc1l1) uptake has been observed in the proximal intestine of Atlantic salmon fed diets including $60 \%$ of full-fat BSF meal (Li et al., 2019).

While real time PCR may represent a valid tool for the early detection of many physiological changes in fish, if applied to nutritional studies its employment should be coupled with other laboratory techniques, like histology and infrared spectroscopy, to obtain a clearer overview. Further research is necessary to overcome the lack of complete and easily available genomic sequences for farmed fish species and to make real-time PCR a 'routine technique' in nutritional studies.

\section{Fish quality}

The consumers' perception process of food quality has been summarised by Fernquist and Ekelund (2014). The authors showed how it is influenced by intrinsic quality attributes (i.e. sensory properties) and intrinsic and extrinsic quality cues which compose quality expectations. Among the firsts, attributes perceived before the consumption like colour, size, and damages are listed. The latter aspects refer to label, packaging, and other external factors. In addition to this, consumers are increasingly focusing on health, ecofriendliness, sustainability of food (Fernqvist and Ekelund, 2014) suggesting that people are looking for deeper sensory pleasures from foods, moving from the sensory properties to health and ethical motivations (Lee and Hwang, 2016). On this regard, the aspects related to animal farming, such as animal right, welfare, and feed assurance, are embedded into the 'new' concept of meat quality (Bernués et al., 2003).
To date, researchers have useful tools to objectify many of the quality parameters, such as physical properties, chemical composition, sensory properties, and consumers' liking which have been applied to answer if BSF meal inclusion in fish diets may affect fish quality and consumers' acceptance.

Physical attributes, such as fillet colour, water holding capacity (WHC) and texture are commonly evaluated by instrumental methods. For instance, colorimeters have been utilised by different authors while performing a colour evaluation of fillets from Atlantic salmon (Bruni et al., 2020a) and rainbow trout (Bruni et al., 2020b; Renna et al., 2017; Secci et al., 2019) fed diets with different inclusion levels of partially or not defatted BSF larvae or prepupae meals. This instrument is designed to assess the colour of a sample in a user-friendly way (easy to use and fast response); however, the punctual reading of the colorimeter requires at least two- or three-points determinations in the same sample. Mancini et al. (2018) instead, captured the whole fillet image through a digital camera, then the colorimetric measurement was carried out by ImageJ software. Irrespective to the instrument utilised, results are generally presented using the CIELab colour space (CIE, 2018), thus splitting the colour into three axes explaining the lightness $\left(\mathrm{L}^{*}\right)$, redness $\left(\mathrm{a}^{*}\right)$, and yellowness $\left(\mathrm{b}^{*}\right)$ values of the sample. In this way, colour perception and its variations are difficult to interpret. Indeed, data showed as $\mathrm{L}^{*}, \mathrm{a}^{*}$, and $b^{*}$ values do not allow an inexpert reader to understand the overall sample colour perception. As a consequence, the differences observed through these methods among the samples did not answer the question: 'were the differences among colour of the samples perceived by an observer?' A useful tool to distinguish different colours is the Delta $\mathrm{E}(\Delta \mathrm{E})$ which is defined as a difference in sensation, as revealed by the name itself: Delta is a Greek letter that stands for the incremental change of a variable, while the ' $E$ ' is the abbreviation for 'Empfindung', the German word for sensation. As a whole, $\Delta \mathrm{E}$ shows the distance between two colours and it is calculated as proposed by Sharma and Bala (2002). Furthermore, Mokrzycki and Tatol (2011) reported different $\Delta \mathrm{E}$ ranges based on the observer perception of the colour difference, as follows: $0<\Delta \mathrm{E}<1-$ observer does not notice the difference; $1<\Delta \mathrm{E}<2-$ only experienced observer can notice the difference; $2<\Delta \mathrm{E}<3.5$ - inexperienced observer also notices the difference; $3.5<\Delta \mathrm{E}<5$ - clear difference in colour is noticed; $\Delta \mathrm{E}>5-$ observer notices two different colours. While looking at the results showed in the literature, it seems that the dietary treatments with BSF did not affect colour values of the rainbow trout fillets (Renna et al., 2017), with the exception of yellowness which was, in some cases lowered (Bruni et al., 2020b; Mancini et al., 2018). In the case of Mancini et al. (2018), where $\Delta \mathrm{E}$ was proposed, control (C) and fillet from trout fed BSF at $25 \%$ of substitution (HI25) showed the same perceived colour ( $\Delta \mathrm{E}$ value $=0.39)$, whereas the $\Delta \mathrm{E}$ values calculated between fillets from $C$ and trout fed $B S F$ 
at $50 \%$ of substitution (HI50) or between HI25 and HI50 fillets were 2.96 and 2.60, respectively, thus being perceived as different. The inconsistent results found until now can be due to the complex interactions composing the overall sample colour. For instance, the flesh colour may be directly affected by the pigments contained in the administered diets (i.e. carotenoids), especially carried by vegetable ingredients (soybean, corn) and BSF meal, in a minor extent (Secci et al., 2019). The addition of astaxanthin in the diet for salmonids, inferable from the high $\mathrm{a}^{*}$ values reported for Atlantic salmon (Bruni et al., 2020a) and rainbow trout (Mancini et al., 2018) fillets, could drown out the effect of dietary ingredients on the different indexes. In addition, lipid oxidation might produce yellow pigments, hence high $b^{*}$ values can be found in fillets with high malondialdehyde equivalents content (MDA-eq.), as in the case of rainbow trout fillets fed on BSF meal-free diet $\left(b^{*}: 5.57\right.$; MDA-eq.: $0.55 \mathrm{mg} / \mathrm{kg}$ fillet) or containing $25 \%$ of full-fat BSF prepupae meal (b*: 4.21; MDA-eq.: $0.30 \mathrm{mg} / \mathrm{kg}$ fillet) (Bruni et al., 2020b).

Considering WHC and texture, these two physical properties are strictly connected, since the WHC (defined as the ability of a food to retain its own water after the application of a pressure, centrifugation, or heating) has proved to play a key role in the formation of food texture (Picard et al., 2017). The most common method adopted for WHC assessment is the one proposed by Hultmann and Rustad (2002) and modified by Iaconisi et al. (2017) based on a centrifugation at $510 \times g$ for $5 \mathrm{~min}$. of a $2 \mathrm{~g}$ sample with known water content. Applying this method to fillets from BSF meal fed fish, Bruni et al. (2020a,b) did not find any significant difference nor among rainbow trout or Atlantic salmon samples. Similarly, Secci et al. (2019) did not show any significant WHC modifications of rainbow trout fillets as affected by BSF meal inclusion in fish diet, either after frozen storage $\left(120\right.$ days at $-10{ }^{\circ} \mathrm{C}$ ) and cooking (boiling at 95-98 ${ }^{\circ} \mathrm{C}$ for $5 \mathrm{~min}$.). An indirect measurement of WHC is obtained by calculating the cooking loss as the weight difference of the fillet before and after the cooking process, according to the formula: $100 \times[$ (raw fillet weight - cooked fillet weight) / raw fillet weight]. Consistently with the WHC assessment, both Borgogno et al. (2017) and Secci et al. (2019) did not underline significant dietary effects on this parameter. Texturometer is generally utilised for texture measurements. The instrument can be equipped with a variety of load cells (as $1 \mathrm{kN}$ or less) and probe (cylindrical, straight blade, Warner-Bratzler) based on the type of test the users want (shear test, texture profile analysis, etc.). Other parameters, such as cross-head speed and the percentage of total deformation have to be set. For this reason, results obtained with different methods and by different researchers are not comparable. Despite this, the textural properties of the fillets from fish fed diets containing BSF meal as alternative protein source seemed not to vary with respect to a control diet, irrespective to the substitution levels (commonly 25, 50, 75\% of FM replaced) and the investigated species (rainbow trout: Borgogno et al., 2017; Secci et al., 2019; Atlantic salmon: Bruni et al., 2020a). Analogous outputs were obtained while using Tenebrio molitor larvae meal as protein source at 25 or $50 \%$ of inclusion for feeding blackspot sea bream, Pagellus bogaraveo (Iaconisi et al., 2017) or rainbow trout (Iaconisi et $a l ., 2018)$. In conclusion, from the instrumentally evaluation of the physical properties of fish fillets emerged that BSF did not impair these items even if colour modification needs to be considered when formulating the experimental diets.

Fish are an important source of energy, essential and nonessential AA, minerals (iodine, selenium, calcium) and vitamins (A, D) and a functional food, being one of the main sources of the long-chain PUFA, as eicosapentaenoic and docosahexaenoic acids (EPA and DHA, respectively). A weekly consumption of around $1.75 \mathrm{~g}$ (for adults) and $3.5 \mathrm{~g}$ (during pregnancy and lactation) of EPA+DHA is highly recommend while following a healthy diet (EFSA, 2015), since they play positive roles in the prevention of body overweight and obesity (Buckley and Howe, 2009) and in the protection against cardiovascular diseases (Bernstein et al., 2012). Hence, fish quality needs to be evaluated considering flesh chemical composition, by means at least of the AA and FA profiles. The methods utilised for these analyses were well established and no significant implementations have occurred in the recent published articles (Belghit et al., 2018; Borgogno et al., 2017; Bruni et al., 2020b,a; Stadtlander et $a l ., 2017)$. Specifically, total AA composition is commonly evaluated using $\mathrm{HCl}$ to hydrolyse fish samples prior to assess a liquid chromatography, as ultra-performance or high pressure ones. Results are commonly expressed as mg AA/g muscle. Concerning FA, once total lipids are extracted from the flesh (methanol:chloroform 2:1 v/v being the most utilised solution) and quantified (gravimetrically), they are subdued to a saponification, then they are methylated to obtain fatty acid methyl esters (FAME). An internal standard as C19:0 (Belghit et al., 2018, 2019a) or C23:0 (Borgogno et al., 2017; Bruni et al., 2020a,b; Secci et al., 2019 ) is added to the samples. Finally, FA composition is determined using a gas-chromatograph $(\mathrm{GC})$ coupled with a flame ionisation detector. The comparison between the recorded chromatograms with the one of a pure standard FAME mix allows the researchers to qualitatively determine the FA profile, thus the results are expressed as \% of total FAME. A quantitative analysis is also possible when using a calibration curve obtained with the FAME standard mix and it is highly suggested. Indeed, the FA content ( $\mathrm{g} / 100 \mathrm{~g}$ muscle) is necessary to retrieve the fundamental information on the EPA+DHA level in the sample, hence, to know if the samples make a valuable contribution to a balanced and healthy diet. Nevertheless, the FA content of fillet from fish fed BSF meal is still scarcely depicted (Belghit et al., 2019a; Bruni et al., 2020b; Renna et al., 2017; Secci et al., 2019). However, as showed by several studies, 
fillet FA profile represents the main weakness of BSF meal inclusion in fish diet, while the total AA both of Atlantic salmon muscle (Belghit et al., 2018, 2019a) and rainbow trout plasma (Sealey et al., 2011) were scarcely affected. Since the early work of St-Hilaire et al. (2007), it was evident that the partial substitution of fishmeal (or of the overall protein content) with BSF meal dramatically increased rainbow trout fillet SFA while decreasing the PUFA fraction. Numerous subsequent studies have confirmed this finding irrespective the fish species investigated (Belghit et al., 2018, 2019a; Borgogno et al., 2017; Bruni et al., 2020a,b; Mancini et al., 2018; Renna et al., 2017; Sealey et al., 2011; Secci et al., 2019; Stadtlander et al., 2017; Zarantoniello et al., 2019). Since BSF meal is rich in lauric acid (12:0), fillet increase in SFA was expected in fish fed BSF diet. In addition, while adding BSF meal to the diet, a reduction of FO, which is the main source of n-3 PUFA, could be necessary to obtain isolipidic and isoenergetic diets. The sum of these elements leads PUFA depletion in fish flesh which, in turn, lowers the overall nutritional quality of the fillet. For this reason, mitigation actions were investigated such as the use of partially defatted BSF meal (Renna et al., 2017), the use of BSF grown on substrates rich in $n-3$ PUFA (St-Hilaire et al., 2007; Truzzi et al., 2020), or the avoidance of FO reduction in feeds (Bruni et al., 2020a). However, interesting information comes from the recent research of Bruni et al. (2020b) who observed attenuated FA profile differences in rainbow trout fed full-fat BSF prepupae meal (inclusion levels set at 0,25 or $50 \%$ ) relative to the dietary differences. Surprisingly, the n-3 PUFA as well as EPA and DHA amounts were not impaired by the dietary intervention, thus resulting in a well-balanced FA profile of the fillets. Standing on our knowledge, Bruni et al. (2020b) linked for the first-time fillet quality and fish lipid metabolism, finding that the formulated practical diets containing full fat BSF meal were effective in increasing pyloric caeca elovl 2 and fads 2 gene expression which in turn positively modified the fillet dietary FA profile. This topic deserves further investigations.

The modifications occurring both on lipid and protein fractions while handling fish fillets, i.e. storage and cooking, promote the development of the fish volatile profile (referred as volatile organic components; VOCs). Recently, Nieva-Echevarría et al. (2018) found significant different volatiles comparing wild and farmed European sea bass which the authors associated to contaminants and diets. In addition, an interaction between fish growing conditions and cooking methods was highlighted by the same authors, because of a different lipid content and FA profile. Hence, a possible effect of BSF meal inclusion in the diet on farmed fish can be also hypothesised. The most common method to evaluate VOCs composition is based on a solid-phase extraction, followed by the GC-mass spectrometry (MS) analysis of the sample headspace, as described in Iglesias and Medina (2008) and modified by Fratini et al. (2012).
For this purpose, the extracted samples were inserted in a vial and heated $\left(60^{\circ} \mathrm{C}\right.$ for $30 \mathrm{~min}$.) to collect VOCs in the headspace of the vial. The VOCs were absorbed on a fibre, as Carboxen ${ }^{\mathrm{TH}} /$ Polydimethylsiloxane $(75 \mu \mathrm{m})$ (Mancini et al., 2018) prior to be GC-analysed. The identification of components is generally conducted by consulting available libraries and comparing with mass spectra and retention times of commercial standards. At the best of authors' knowledge, the articles showing the VOCs content are limited in literature. Among these, the paper by Mancini et al. (2018) offers interesting results while assessing VOCs profile of BSF larvae meal, rainbow trout feeds (control, 25 or $50 \%$ of FM substitution with partially defatted BSF larvae meal), and fish fillets. Although the dietary VOCs profile was effectively different, Mancini et al. (2018) showed that the VOCs profile of fillets was scarcely affected by the presence of BSF in the diet for rainbow trout, irrespective the substitution level. Such result could be attributable both to a molecule degradation, occurring during the digestive process of the fish, and/or to an absent muscle deposition. An innovative approach was adopted by Bruni et al. (2020a) while evaluating the volatile composition of raw Atlantic salmon fed diets containing 25 to $75 \%$. BSF meal larvae. The proton transfer reaction-time of flight-mass spectrometer (PTR-ToF-MS) technique offers technical advantages as a rapid data collection (100 s for each sample) and the possibility to evaluate VOCs of the whole sample at room temperature, hence avoiding sample manipulation (mincing, solid phase extraction), and heating. Despite its pros, PTR-ToF-MS technique requires numerous and timeconsuming offline activities, corresponding to the spectracalibration, raw data acquisition and correction (elimination of peaks imputable to water chemistry, interfering ions, and also elimination of all peaks for which the average concentrations are lower than an established threshold), and tentative peak identification based on literature or libraries. This last step appears to be critical, since 18 out of 29 VOCs were quantified without being identified, as depicted in Bruni et al. (2020a) results. Concerning the effect of BSF meal on Atlantic salmon, data agree with Mancini et al. (2018) since no different VOCs profiles emerged among the samples.

In conclusion, the inclusion of BSF meal up to $25 \%$ did not jeopardise fillet physical and nutritional characteristics, while upper inclusion levels mainly affect colour and FA composition. Despite this, understanding if and how the diet affects fillet sensory properties and consumers' liking is necessary to positively judge BSF meal as protein source for aquafeeds. The early study by Sealey et al. (2011) approached the topic through a sensory evaluation of rainbow trout fillets conducted by 30 untrained panellists (14 males and 16 females, from 18 to 65 years old). The method adopted was a triangle difference test, which consists to indicate the odd sample in a set of three blinded samples. Panellists were also free to express the reason of 
their choice and what were the attributes making different the sample perception. Sealey et al. (2011) showed that people were unable to discriminate between fillets from rainbow trout fed a control diet (containing anchovy meal) and the experimental diets containing normal and enriched (with n-3 PUFA) BSF prepupae meal. Recently, the intensity of the perceived sensory attributes of fish fed BSF meal was evaluated by using trained (Belghit et al., 2018; Borgogno et al., 2017) or untrained assessors (Stadtlander et al., 2017). For instance, Stadtlander et al. (2017) proposed an organoleptic test on steam-cooked fillets from rainbow trout fed a diet where $46 \%$ of FM was substituted by BSF meal. Fifteen untrained panellists were asked to rate different sensory characteristics (odour, colour, texture and taste) on a scale between 0 (does not apply) to 9 (applies fully). Similarly, Belghit et al. (2019a) tested raw and baked fillets from Atlantic salmon fed diets at increasing substitution level of FM with BSF meal. Ten trained assessors were asked to evaluate the intensity of several sensory attributes (odour, colour, texture) by using a 15-cm non-structured continuous scale. Results from the previous mentioned studies mostly agreed. Indeed, the sole significant variation detected was a difference in fillet colour even if Stadtlander et al. (2017) found darker flesh in fillets from trout fed insect meal, while the salmon fed $66 \%$ of BSF meal had fillets significantly less coloured than those of the group fed the control diet (without BSF) in Belghit's et al. (2018). An innovative approach distinguishes the work of Borgogno et al. (2017), who found that BSF larvae meal inclusion at 20 and $40 \%$ in rainbow trout diets affected the fillet sensory profile when assessed through a descriptive analysis and a temporal dominance of sensation (TDS) methods by trained panellists. Several outcomes can be retrieved from the proposed methodology, both in terms of sensorial attributes related to aroma, texture, appearance, and tactile sensations and of the sensory perception process during all the chewing. The main criticism of these methods is about the training sessions. Indeed, both descriptive analysis and TDS require three training sessions of about $60 \mathrm{~min}$. each, that means overall 6 sessions dedicated for training more the time necessary for sensory evaluation. Consumers' expectation and willingness to pay were investigated by Ferrer Llagostera et al. (2019) while Bruni et al. (2020a) focused on consumers' liking. On one hand, discrete choice experiment (DCE) was chosen by Ferrer Llagostera et al. (2019) to understand the preferences of Spanish people towards farmed gilthead sea bream fed diets containing insect meal. DCE is basically an on-line questionnaire which proposes different products (in this case gilthead sea bream fed insect meal) at different price levels in several purchase situations. In the case of Ferrer Llagostera et al. (2019), the purpose was to identify the consumers' trade-offs in their choice decision. On the other hand, consumers' test was selected by Bruni et al. (2020a) to investigate Italian's liking and intention of re-consumption of Atlantic salmon obtained by administering BSF meal to fish as protein source in aquafeed. The authors served Atlantic salmon blinded samples at 80 consumers, asking them to express their like or dislike (using a 9-points scale) for a series of sensory attributes. Interestingly, Ferrer Llagostera et al. (2019) highlighted that people had a good opinion of gilthead sea bream farmed using insects as feed ingredients but they expected these fish to taste 'less'. On the contrary, the hedonic evaluation proposed by Bruni et al. (2020a), conducted under no informed condition (consumers did not know what was the dietary treatment), gave important information. Firstly, people perceived as too pale the colour of fillets from groups fed diets with 66 and 100\% BSF meal inclusion levels and the flesh resulted slightly firmer than the control group (0\% BSF meal), in line with the instrumental analyses (Belghit et al., 2018). Moreover, Bruni et al. (2020a) point out that increasing substitution level of BSF meal (0, 33, 66 and 100\%) in Atlantic salmon diet did not counteract consumers' overall liking and intention of re-consumption ( $>70 \%$ of positive answers). The results from Spanish and Italian research groups give reason to hope for a complete consumers' acceptance of insect meal as protein source in the aquaculture sector.

\section{Conclusions and future perspectives}

Several analytical methods and laboratory techniques are presently available to deepen our knowledge about fish welfare and quality in response to diets including BSF meal. While these laboratory techniques have been used in fish and other animal's responses to all kind of alternative ingredients, a number of studies have recently showed their suitability for a better understanding of fish responses to BSF based diets. Results evidenced that certain dietary inclusion levels of BSF meal are able to promote fish health, welfare and quality of the product. However, there is a lack of information about long-term use of these diets. For this reason, scientists should perform further studies over longer periods of time and possibly over the whole fish life cycle. On this regard, emphasis should be given to nutritional programming experiments as well as the possible effect of these new diets on fish reproduction. The laboratory methodological approaches included in this review article may serve as a starting point for this further research.

Considering these last aspects, the authors suggest a constructive crosstalk between research and industry to sustain the development of a high quality and sustainable aquaculture.

\section{Acknowledgements}

This study was partially funded by Ricerca Scientifica 2017 Cariverona, NUTRIFISH project N. 2017.0571 to Ike Olivotto. 


\section{Conflict of interest}

The authors declare no conflict of interest.

\section{References}

Ahmed, N. and Thompson, S., 2019. The blue dimensions of aquaculture: a global synthesis. Science of the Total Environment 652: 851-861. https://doi.org/10.1016/j.scitotenv.2018.10.163

Apper, E., Weissman, D., Respondek, F., Guyonvarch, A., Baron, F., Boisot, P., Rodiles, A. and Merrifield, D.L., 2016. Hydrolysed wheat gluten as part of a diet based on animal and plant proteins supports good growth performance of Asian seabass (Lates calcarifer), without impairing intestinal morphology or microbiota. Aquaculture 453: 40-48. https://doi.org/10.1016/j.aquaculture.2015.11.018

Ashley, P.J., 2007. Fish welfare: current issues in aquaculture. Applied Animal Behaviour Science 104(3-4): 199-235. https://doi. org/10.1016/j.applanim.2006.09.001

Askarian, F., Zhou, Z., Olsen, R.E., Sperstad, S. and Ringø, E., 2012. Culturable autochthonous gut bacteria in Atlantic salmon (Salmo salar L.) fed diets with or without chitin. Characterization by $16 \mathrm{~S}$ rRNA gene sequencing, ability to produce enzymes and in vitro growth inhibition of four fish pathogens. Aquaculture 326-329: 1-8. https://doi.org/10.1016/j.aquaculture.2011.10.016

Aziza, A., Awadin, W. and Orma, A., 2013. Effect of dietary substitution of cod liver oil by vegetable oils on growth performance, body composition, lipid peroxidation, liver and muscle histopathological state in Nile tilapia (Oreochromis niloticus). Journal of Fisheries and Aquaculture 4(2): 87-94. http://dx.doi.org/10.9735/09769927.4.2.87-94

Baeverfjord, G. and Krogdahl, A., 1996. Development and regression of soybean meal induced enteritis in Atlantic salmon, Salmo salar L., distal intestine: a comparison with the intestines of fasted fish. Journal of Fish Diseases 19(5): 375-387. https://doi. org/10.1046/j.1365-2761.1996.d01-92.x

Balcázar, J.L., De Blas, I., Ruiz-Zarzuela, I., Cunningham, D., Vendrell, D. and Múzquiz, J.L., 2006. The role of probiotics in aquaculture. Veterinary Microbiology 114(3-4): 173-186. https:// doi.org/10.1016/j.vetmic.2006.01.009

Barragan-Fonseca, K.B., Dicke, M. and Van Loon, J.J.A., 2017. Nutritional value of the black soldier fly (Hermetia illucens L.) and its suitability as animal feed - a review. Journal of Insects as Food Feed 3(2): 105-120. https://doi.org/10.3920/JIFF2016.0055

Barreto-Curiel, F., Parés-Sierra, G., Correa-Reyes, G., Durazo-Beltrán, E. and Viana, M.T., 2016. Total and partial fishmeal substitution by poultry by-product meal (Petfood grade) and enrichment with acid fish silage in aquafeeds for juveniles of rainbow trout Oncorhynchus mykiss. Latin American Journal of Aquatic Research 44(2): 327-335. https://doi.org/10.3856/vol44-issue2-fulltext-13

Barroso, F.G., De Haro, C., Sánchez-Muros, M.J., Venegas, E., MartínezSánchez, A. and Pérez-Bañón, C., 2014. The potential of various insect species for use as food for fish. Aquaculture 422-423: 193-201. https://doi.org/10.1016/j.aquaculture.2013.12.024
Barton, B.A., 2002. Stress in fishes: a diversity of responses with particular reference to changes in circulating corticosteroids. Integrative and Comparative Biology 42(3): 517-525. https://doi. org/10.1093/icb/42.3.517

Basto-Silva, C., Guerreiro, I., Oliva-Teles, A. and Neto, B., 2019. Life cycle assessment of diets for gilthead seabream (Sparus aurata) with different protein/carbohydrate ratios and fishmeal or plant feedstuffs as main protein sources. The International Journal of Life Cycle Assessment 24: 2023-2034. https://doi.org/10.1007/ s11367-019-01625-7

Beier, S. and Bertilsson, S., 2013. Bacterial chitin degradationmechanisms and ecophysiological strategies. Frontiers in Microbiology 4: 149. https://doi.org/10.3389/fmicb.2013.00149

Belforti, M., Gai, F., Lussiana, C., Renna, M., Malfatto, V., Rotolo, L., De Marco, M., Dabbou, S., Schiavone, A., Zoccarato, I. and Gasco, L., 2015. Tenebrio molitor meal in rainbow trout (Oncorhynchus mykiss) diets: effects on animal performance, nutrient digestibility and chemical composition of fillets. Italian Journal of Animal Science 14(4): 4170. https://doi.org/10.4081/ijas.2015.4170

Belghit, I., Liland, N.S., Gjesdal, P., Biancarosa, I., Menchetti, E., Li, Y., Waagbø, R., Krogdahl, Å. and Lock, E.J., 2019a. Black soldier fly larvae meal can replace fish meal in diets of sea-water phase Atlantic salmon (Salmo salar). Aquaculture 503: 609-619. https:// doi.org/10.1016/j.aquaculture.2018.12.032

Belghit, I., Liland, N.S., Waagbø, R., Biancarosa, I., Pelusio, N., Li, Y., Krogdahl, Å. and Lock, E.J., 2018. Potential of insect-based diets for Atlantic salmon (Salmo salar). Aquaculture 491: 72-81. https:// doi.org/10.1016/j.aquaculture.2018.03.016

Belghit, I., Waagbø, R., Lock, E.-J. and Liland, N.S., 2019b. Insectbased diets high in lauric acid reduce liver lipids in freshwater Atlantic salmon. Aquaculture Nutrition 25: 343-357. https://doi. org/10.1111/anu.12860

Berggren, Å., Jansson, A. and Low, M., 2019. Approaching ecological sustainability in the emerging insects-as-food industry. Trends in Ecology \& Evolution 34(2): 132-138. https://doi.org/10.1016/j. tree.2018.11.005

Bernstein, A.M., Ding, E.L., Willett, W.C. and Rimm, E.B., 2012. A meta-analysis shows that docosahexaenoic acid from algal oil reduces serum triglycerides and increases hdl-cholesterol and ldlcholesterol in persons without coronary heart disease. The Journal of Nutrition 142(1): 99-104. https://doi.org/10.3945/jn.111.148973

Bernués, A., Olaizola, A. and Corcoran, K., 2003. Extrinsic attributes of red meat as indicators of quality in Europe: an application for market segmentation. Food Quality and Preference 14(4): 265-276. https://doi.org/10.1016/S0950-3293(02)00085-X

Bertucci, J.I., Blanco, A.M., Sundarrajan, L., Rajeswari, J.J., Velasco, C. and Unniappan, S., 2019. Nutrient regulation of endocrine factors influencing feeding and growth in fish. Frontiers in Endocrinology 10: 83. https://doi.org/10.3389/fendo.2019.00083

Blaufuss, P.C., Bledsoe, J.W., Gaylord, T.G., Sealey, W.M., Overturf, K.E. and Powell, M.S., 2020. Selection on a plant-based diet reveals changes in oral tolerance, microbiota and growth in rainbow trout (Oncorhynchus mykiss) when fed a high soy diet. Aquaculture 525: 735287. https://doi.org/10.1016/j.aquaculture.2020.735287 
Borgogno, M., Dinnella, C., Iaconisi, V., Fusi, R., Scarpaleggia, C., Schiavone, A., Monteleone, E., Gasco, L. and Parisi, G., 2017. Inclusion of Hermetia illucens larvae meal on rainbow trout (Oncorhynchus mykiss) feed: effect on sensory profile according to static and dynamic evaluations. Journal of the Science of Food and Agriculture 97(10): 3402-3411. https://doi.org/10.1002/ jsfa.8191

Bosch, G., Van Zanten, H.H.E., Zamprogna, A., Veenenbos, M., Meijer, N.P., Van der Fels-Klerx, H.J. and Van Loon, J.J.A., 2019. Conversion of organic resources by black soldier fly larvae: legislation, efficiency and environmental impact. Journal of Cleaner Production 222: 355-363. https://doi.org/10.1016/j.jclepro.2019.02.270

Bosi, G., Giari, L., DePasquale, J.A., Carosi, A., Lorenzoni, M. and Dezfuli, B.S., 2017. Protective responses of intestinal mucous cells in a range of fish-helminth systems. Journal of Fish Diseases 40(8): 1001-1014. https://doi.org/10.1111/jfd.12576

Brennan, N.M., Ward, A.C., Beresford, T.P., Fox, P.F., Goodfellow, M. and Cogan, T.M., 2002. Biodiversity of the bacterial flora on the surface of a smear cheese. Applied and Environmental Microbiology 68(2): 820-830. https://doi.org/10.1128/AEM.68.2.820-830.2002

Brijs, J., Sandblom, E., Axelsson, M., Sundell, K., Sundh, H., Huyben, D., Broström, R., Kiessling, A., Berg, C. and Gräns, A., 2018. The final countdown: continuous physiological welfare evaluation of farmed fish during common aquaculture practices before and during harvest. Aquaculture 495: 903-911. https://doi.org/10.1016/j. aquaculture.2018.06.081

Bruni, L., Belghit, I., Lock, E.J., Secci, G., Taiti, C. and Parisi, G., 2020a. Total replacement of dietary fish meal with black soldier fly (Hermetia illucens) larvae does not impair physical, chemical or volatile composition of farmed Atlantic salmon (Salmo salar L.). Journal of Science of Food and Agriculture 100(3): 1038-1047. https://doi.org/10.1002/jsfa.10108

Bruni, L., Pastorelli, R., Viti, C., Gasco, L. and Parisi, G., 2018. Characterisation of the intestinal microbial communities of rainbow trout (Oncorhynchus mykiss) fed with Hermetia illucens (black soldier fly) partially defatted larva meal as partial dietary protein source. Aquaculture 487: 56-63. https://doi.org/10.1016/j. aquaculture.2018.01.006

Bruni, L., Randazzo, B., Cardinaletti, G., Zarantoniello, M., Mina, F., Secci, G., Tulli, F., Olivotto, I. and Parisi, G., 2020b. Dietary inclusion of full-fat Hermetia illucens prepupae meal in practical diets for rainbow trout (Oncorhynchus mykiss): lipid metabolism and fillet quality investigations. Aquaculture 529: 735678. https:// doi.org/10.1016/j.aquaculture.2020.735678

Buckley, J.D. and Howe, P.R.C., 2009. Anti-obesity effects of long-chain omega-3 polyunsaturated fatty acids. Obesity Reviews 10(6): 648659. https://doi.org/10.1111/j.14.67-789X.2009.00584.x

Bui-Nguyen, T.M., Baer, C.E., Lewis, J.A., Yang, D., Lein, P.J. and Jackson, D.A., 2015. Dichlorvos exposure results in large scale disruption of energy metabolism in the liver of the zebrafish, Danio rerio. BMC Genomics 16: 853. https://doi.org/10.1186/s12864015-1941-2
Caimi, C., Gasco, L., Biasato, I., Malfatto, V., Varello, K., Prearo, M., Pastorino, P., Bona, M.C., Francese, D.R., Schiavone, A., Elia, A.C., Dörr, A.J.M. and Gai, F., 2020a. Could dietary black soldier fly meal inclusion affect the liver and intestinal histological traits and the oxidative stress biomarkers of Siberian sturgeon (Acipenser baerii) juveniles? Animals 10: 155. https://doi.org/10.3390/ani10010155

Caimi, C., Renna, M., Lussiana, C., Bonaldo, A., Gariglio, M., Meneguz, M., Dabbou, S., Schiavone, A., Gai, F., Elia, A.C., Prearo, M. and Gasco, L., 2020b. First insights on black soldier fly (Hermetia illucens $\mathrm{L}$.) larvae meal dietary administration in Siberian sturgeon (Acipenser baerii Brandt) juveniles. Aquaculture 515: 734539. https://doi.org/10.1016/j.aquaculture.2019.734539

Cardinaletti, G., Randazzo, B., Messina, M., Zarantoniello, M., Giorgini, E., Zimbelli, A., Bruni, L., Parisi, G., Olivotto, I. and Tulli, F., 2019. Effects of graded dietary inclusion level of full-fat Hermetia illucens prepupae meal in practical diets for rainbow trout (Oncorhynchus mykiss). Animals 9: 251. https://doi.org/10.3390/ani9050251

Dama, L.B. and Pathan, A.V., 2019. Histochemical analysis of gastrointestinal mucosubstances of fresh water fish Mastacembelus armatus infected by helminth parasite Circumonco bothrium sp. Journal of Animal and Feed Research 9(6): 265-269. https://doi. org/10.36380/SCIL.2019.OJAFR37

Daprà, F., Geurden, I., Corraze, G., Bazin, D., Zambonino-Infante, J.L. and Fontagné-Dicharry, S., 2011. Physiological and molecular responses to dietary phospholipids vary between fry and early juvenile stages of rainbow trout (Oncorhynchus mykiss). Aquaculture 319(3-4): 377-384. https://doi.org/10.1016/j.aquaculture.2011.07.016 Das Neves Cardoso, N., Da Silveira Firmiano, E.M., Gomes, I.D., Nascimento, A.A., Sales, A. and Araújo, F.G., 2015. Histochemical and immunohistochemical study on endocrine cells (5HT, GAS, and SST) of the gastrointestinal tract of a teleost, the characin Astyanax bimaculatus. Acta Histochemica 117(7): 595-604. https:// doi.org/10.1016/j.acthis.2015.05.007

Devic, E., Leschen, W., Murray, F. and Little, D.C., 2018. Growth performance, feed utilization and body composition of advanced nursing Nile tilapia (Oreochromis niloticus) fed diets containing black soldier fly (Hermetia illucens) larvae meal. Aquaculture Nutrition 24(1): 416-423. https://doi.org/10.1111/anu.12573

Donaldson, G.P., Lee, S.M. and Mazmanian, S.K., 2015. Gut biogeography of the bacterial microbiota. Nature Reviews Microbiology 14: 20-32. https://doi.org/10.1038/nrmicro3552

Dumas, A., Raggi, T., Barkhouse, J., Lewis, E. and Weltzien, E., 2018. The oil fraction and partially defatted meal of black soldier fly larvae (Hermetia illucens) affect differently growth performance, feed efficiency, nutrient deposition, blood glucose and lipid digestibility of rainbow trout (Oncorhynchus mykiss). Aquaculture 492: 24-34. https://doi.org/10.1016/j.aquaculture.2018.03.038

Egerton, S., Culloty, S., Whooley, J., Stanton, C. and Ross, R.P., 2018. The gut microbiota of marine fish. Frontiers in Microbiology 9: 873. https://doi.org/10.3389/fmicb.2018.00873

EL-Haroun, E.R., Azevedo, P.A. and Bureau, D.P., 2009. High dietary incorporation levels of rendered animal protein ingredients on performance of rainbow trout Oncorhynchus mykiss (Walbaum, 1972). Aquaculture 290(3-4): 269-274. https://doi.org/10.1016/j. aquaculture.2009.02.014 
Elia, A.C., Capucchio, M.T., Caldaroni, B., Magara, G., Dörr, A.J.M., Biasato, I., Biasibetti, E., Righetti, M., Pastorino, P., Prearo, M., Gai, F., Schiavone, A. and Gasco, L., 2018. Influence of Hermetia illucens meal dietary inclusion on the histological traits, gut mucin composition and the oxidative stress biomarkers in rainbow trout (Oncorhynchus mykiss). Aquaculture 496: 50-57. https://doi. org/10.1016/j.aquaculture.2018.07.009

European Commission, 2008. Directive 2008/98/EC of the European Parliament and of the Council of 19 November 2008 on waste and repealing certain Directives (text with EEA relevance). Official Journal of the European Union L 312: 3-30.

European Commission, 2013. Commission Regulation No 56/2013 of 16 January 2013 amending Annexes I and IV to Regulation (EC) No 999/2001 of the European Parliament and of the Council laying down rules for the prevention, control and eradication of certain transmissible spongiform encephalopathies. Official Journal of the European Union L 21: 3-16.

European Food Safety Authority (EFSA), 2009. Statement of the animal health and welfare panel (AHAW): knowledge gaps and research needs for the welfare of farmed fish. EFSA Journal 7(6): 1145. https:// doi.org/10.2903/j.efsa.2009.1145

European Food Safety Authority (EFSA), 2015. Statement on the benefits of fish/seafood consumption compared to the risks of methylmercury in fish/seafood. EFSA Journal 13(1): 3982. https://10.2903/j.efsa.2015.3982

Ewald, N., Vidakovic, A., Langeland, M., Kiessling, A., Sampels, S. and Lalander, C., 2020. Fatty acid composition of black soldier fly larvae (Hermetia illucens) - possibilities and limitations for modification through diet. Waste Management 102: 40-47. https:// doi.org/10.1016/j.wasman.2019.10.014

Fehrmann-Cartes, K., Coronado, M., Hernández, A.J., Allende, M.L. and Feijoo, C.G., 2019. Anti-inflammatory effects of aloe vera on soy meal-induced intestinal inflammation in zebrafish. Fish \& Shellfish Immunology 95: 564-573. https://doi.org/10.1016/j.fsi.2019.10.075

Fernqvist, F. and Ekelund, L., 2014. Credence and the effect on consumer liking of food - a review. Food Quality and Preference 32: 340-353. https://doi.org/10.1016/j.foodqual.2013.10.005

Ferrer Llagostera, P., Kallas, Z., Reig, L. and Amores de Gea, D., 2019. The use of insect meal as a sustainable feeding alternative in aquaculture: current situation, Spanish consumers' perceptions and willingness to pay. Journal of Cleaner Production 229: 10-21. https://doi.org/10.1016/j.jclepro.2019.05.012

Food and Agriculture Organisation (FAO), 2016. The state of world fisheries and aquaculture 2016 - contributing to food security and nutrition for all. FAO, Rome, Italy, 200 pp. Available at: http://www. fao.org/3/a-i5555e.pdf

Food and Agriculture Organisation (FAO), 2018. State of world fisheries and aquaculture 2018 - meeting the sustainable development goals. FAO, Rome, Italy, 210 pp. Available at: http://www.fao.org/3/ i9540en/i9540en.pdf

Francis, G., Makkar, H. and Becker, K., 2001. Antinutritional factors present in plant-derived alternate fish feed ingredients and their effects in fish. Aquaculture 199(3-4): 197-227. https://doi. org/10.1016/S0044-8486(01)00526-9
Fratini, G., Lois, S., Pazos, M., Parisi, G. and Medina, I., 2012. Volatile profile of Atlantic shellfish species by HS-SPME GC/MS. Food Research International 48(2): 856-865. https://doi.org/10.1016/j. foodres.2012.06.033

Gajardo, K., Jaramillo-Torres, A., Kortner, T.M., Merrifield, D.L., Tinsley, J., Bakke, A.M. and Krogdahl, Å., 2017. Alternative protein sources in the diet modulate microbiota and functionality in the distal intestine of Atlantic salmon (Salmo salar). Applied Environmental Microbiology 83(5): e02615-16. https://doi. org/10.1128/AEM.02615-16

Gasco, L., Acuti, G., Bani, P., Dalle Zotte, A., Danieli, P., De Angelis, A., Fortina, R., Marino, R., Parisi, G., Piccolo, G., Pinotti, L., Prandini, A., Schiavone, A., Terova, G., Tulli, F. and Roncarati, A., 2020. Insect and fish by-products as sustainable alternatives to conventional animal proteins in animal nutrtion. Italian Journal of Animal Science 19(1): 360-372. https://doi.org/10.1080/1828051X.2020.1743209

Gasco, L., Finke, M. and Van Huis, A., 2018. Can diets containing insects promote animal health? Journal of Insects as Food and Feed 4(1): 1-4. https://doi.org/10.3920/JIFF2018.x001

Gatlin, D.M., Barrows, F.T., Brown, P., Dabrowski, K., Gaylord, T.G., Hardy, R.W., Herman, E., Hu, G., Krogdahl, Å., Nelson, R., Overturf, K., Rust, M., Sealey, W., Skonberg, D., Souza, E.J., Stone, D., Wilson, R. and Wurtele, E., 2007. Expanding the utilization of sustainable plant products in aquafeeds: a review. Aquaculture Research 38(6): 551-579. https://doi.org/10.1111/j.1365-2109.2007.01704.x

Gerile, S. and Pirhonen, J., 2017. Replacement of fishmeal with corn gluten meal in feeds for juvenile rainbow trout (Oncorhynchus mykiss) does not affect oxygen consumption during forced swimming. Aquaculture 479: 616-618. https://doi.org/10.1016/j. aquaculture.2017.07.002

Ghanbari, M., Kneifel, W. and Domig, K.J., 2015. A new view of the fish gut microbiome: advances from next-generation sequencing. Aquaculture 448: 464-475. https://doi.org/10.1016/j. aquaculture.2015.06.033

Giannetto, A., Oliva, S., Ceccon Lanes, C.F., de Araújo Pedron, F., Savastano, D., Baviera, C., Parrino, V., Lo Paro, G., Spanò, N.C., Cappello, T., Maisano, M., Mauceri, A. and Fasulo, S., 2020. Hermetia illucens (Diptera: Stratiomydae) larvae and prepupae: biomass production, fatty acid profile and expression of key genes involved in lipid metabolism. Journal of Biotechnology 307: 44-54. https://doi.org/10.1016/j.jbiotec.2019.10.015

Giorgini, E., Randazzo, B., Gioacchini, G., Cardinaletti, G., Vaccari, L., Tibaldi, E. and Olivotto, I., 2018a. New insights on the macromolecular building of rainbow trout (O. mykiss) intestine: FTIR Imaging and histological correlative study. Aquaculture 497: 1-9. https://doi.org/10.1016/j.aquaculture.2018.07.032

Giorgini, E., Sabbatini, S., Rocchetti, R., Notarstefano, V., Rubini, C., Conti, C., Orilisi, G., Mitri, E., Bedolla, D.E. and Vaccari, L., 2018b. In vitro FTIR microspectroscopy analysis of primary oral squamous carcinoma cells treated with cisplatin and 5-fluorouracil: a new spectroscopic approach for studying the drug-cell interaction. Analyst 143: 3317-3326. https://doi.org/10.1039/c8an00602d

Givens, C., Ransom, B., Bano, N. and Hollibaugh, J., 2015. Comparison of the gut microbiomes of 12 bony fish and 3 shark species. Marine Ecology Progress Series 518: 209-223. https://doi.org/10.3354/ meps11034 
Gobbi, P., Martínez-Sánchez, A. and Rojo, S., 2013. The effects of larval diet on adult life-history traits of the black soldier fly, Hermetia illucens (Diptera: Stratiomyidae). European Journal of Entomology 110(3): 461-468. https://doi.org/10.14411/eje.2013.061

Godfray, H.C.J., Beddington, J.R., Crute, I.R., Haddad, L., Lawrence, D., Muir, J.F., Pretty, J., Robinson, S., Thomas, S.M. and Toulmin, C., 2010. Food security: the challenge of feeding 9 billion people. Science 327(5967): 812-818. https://doi.org/10.1126/science.1185383

Groschwitz, K.R. and Hogan, S.P., 2009. Intestinal barrier function: molecular regulation and disease pathogenesis. Journal of Allergy and Clinical Immunology 124(1): 3-20. https://doi.org/10.1016/j. jaci.2009.05.038

$\mathrm{Gu}, \mathrm{X}$. and Li, D., 2004. Effect of dietary crude protein level on villous morphology, immune status and histochemistry parameters of digestive tract in weaning piglets. Animal Feed Science and Technology 114(1-4): 113-126. https://doi.org/10.1016/j.anifeedsci.2003.12.008

Gudiña, E.J., Fernandes, E.C., Rodrigues, A.I., Teixeira, J.A. and Rodrigues, L.R., 2015. Biosurfactant production by Bacillus subtilis using corn steep liquor as culture medium. Frontiers in Microbiology 6: 59. https://doi.org/10.3389/fmicb.2015.00059

Gutiérrez, E., Lozano, S. and Guillén, J., 2020. Efficiency data analysis in EU aquaculture production. Aquaculture 520: 734962. https:// doi.org/10.1016/j.aquaculture.2020.734962

Hardy, R.W., 2010. Utilization of plant proteins in fish diets: effects of global demand and supplies of fishmeal. Aquaculture Research 41(5): 770-776. https://doi.org/10.1111/j.1365-2109.2009.02349.x

Hasnain, S.Z., Gallagher, A.L., Grencis, R.K. and Thornton, D.J., 2013. A new role for mucins in immunity: insights from gastrointestinal nematode infection. The International Journal of Biochemistry \& Cell Biology 45(2): 364-374. https://doi.org/10.1016/j. biocel.2012.10.011

Hatlen, B., Jakobsen, J. V., Crampton, V., Alm, M., Langmyhr, E., Espe, M., Hevrøy, E.M., Torstensen, B.E., Liland, N. and Waagbø, R., 2015. Growth, feed utilization and endocrine responses in Atlantic salmon (Salmo salar) fed diets added poultry by-product meal and blood meal in combination with poultry oil. Aquaculture Nutrition 21(5): 714-725. https://doi.org/10.1111/anu.12194

Heikkinen, J., Vielma, J., Kemiläinen, O., Tiirola, M., Eskelinen, P., Kiuru, T., Navia-Paldanius, D. and Von Wright, A., 2006. Effects of soybean meal based diet on growth performance, gut histopathology and intestinal microbiota of juvenile rainbow trout (Oncorhynchus mykiss). Aquaculture 261(1): 259-268. https://doi.org/10.1016/j. aquaculture.2006.07.012

Henry, M., Gasco, L., Piccolo, G. and Fountoulaki, E., 2015. Review on the use of insects in the diet of farmed fish: past and future. Animal Feed Science and Technology 203: 1-22. https://doi.org/10.1016/j. anifeedsci.2015.03.001

Hua, K., Cobcroft, J.M., Cole, A., Condon, K., Jerry, D.R., Mangott, A., Praeger, C., Vucko, M.J., Zeng, C., Zenger, K. and Strugnell, J.M., 2019. The future of aquatic protein: implications for protein sources in aquaculuture diets. One Earth 1(3): 316-329. https://doi. org/10.1016/j.oneear.2019.10.018

Hultmann, L. and Rustad, T., 2002. Textural changes during iced storage of salmon (Salmo salar) and cod (Gadus morhua). Journal of Aquatic Food Product Technology 11(3-4): 105-123. https://doi. org/10.1300/J030v11n03_09
Huyben, D., Vidaković, A., Werner Hallgren, S. and Langeland, M., 2019. High-throughput sequencing of gut microbiota in rainbow trout (Oncorhynchus mykiss) fed larval and pre-pupae stages of black soldier fly (Hermetia illucens). Aquaculture 500: 485-491. https://doi.org/10.1016/j.aquaculture.2018.10.034

Iaconisi, V., Bonelli, A., Pupino, R., Gai, F. and Parisi, G., 2018. Mealworm as dietary protein source for rainbow trout: body and fillet quality traits. Aquaculture 484: 197-204. https://doi. org/10.1016/j.aquaculture.2017.11.034

Iaconisi, V., Marono, S., Parisi, G., Gasco, L., Genovese, L., Maricchiolo, G., Bovera, F. and Piccolo, G., 2017. Dietary inclusion of Tenebrio molitor larvae meal: effects on growth performance and final quality treats of blackspot sea bream (Pagellus bogaraveo). Aquaculture 476: 49-58. https://doi.org/10.1016/j.aquaculture.2017.04.007

Iglesias, J. and Medina, I., 2008. Solid-phase microextraction method for the determination of volatile compounds associated to oxidation of fish muscle. Journal of Chromatography A 1192(1): 9-16. https:// doi.org/10.1016/j.chroma.2008.03.028

International Commission on Illumination (CIE), 2018. Colorimetry, $4^{\text {th }}$ edition. Technical Report, International Commission on Illumination, Vienna, Austria, 111 pp. https://doi.org/10.25039/ TR.015.2018

Józefiak, A., Nogales-Mérida, S., Mikołajczak, Z., Rawski, M., Kierończyk, B. and Mazurkiewicz, J., 2019a. The utilization of fullfat insect meal in rainbow trout (Oncorhynchus mykiss) nutrition: the effects on growth performance, intestinal microbiota and gastrointestinal tract histomorphology. Annals of Animal Science 19(3): 747-765. https://doi.org/10.2478/aoas-2019-0020

Józefiak, A., Nogales-Mérida, S., Rawski, M., Kierończyk, B. and Mazurkiewicz, J., 2019b. Effects of insect diets on the gastrointestinal tract health and growth performance of Siberian sturgeon (Acipenser baerii Brandt, 1869). BMC Veterinary Research 15: 384. https://doi. org/10.1186/s12917-019-2070-y

Kim, D.H., Brunt, J. and Austin, B., 2007. Microbial diversity of intestinal contents and mucus in rainbow trout (Oncorhynchus mykiss). Journal of Applied Microbiology 102(6): 1654-1664. https:// doi.org/10.1111/j.1365-2672.2006.03185.x

Kinnebrew, M.A. and Pamer, E.G., 2012. Innate immune signaling in defense against intestinal microbes. Immunological Reviews 245(1): 113-131. https://doi.org/10.1111/j.1600-065X.2011.01081.x Knudsen, D., Jutfelt, F., Sundh, H., Sundell, K., Koppe, W. and Frøkiær, H., 2008. Dietary soya saponins increase gut permeability and play a key role in the onset of soyabean-induced enteritis in Atlantic salmon (Salmo salar L.). British Journal of Nutrition 100(1): 120129. https://doi.org/10.1017/S0007114507886338

Kokou, F., Con, P., Barki, A., Nitzan, T., Slosman, T., Mizrahi, I. and Cnaani, A., 2019. Short- and long-term low-salinity acclimation effects on the branchial and intestinal gene expression in the European seabass (Dicentrarchus labrax). Comparative Biochemistry and Physiology Part A: Molecular \& Integrative Physiology 231: 1118. https://doi.org/10.1016/j.cbpa.2019.01.018 
Kroeckel, S., Harjes, A.G.E., Roth, I., Katz, H., Wuertz, S., Susenbeth, A. and Schulz, C., 2012. When a turbot catches a fly: evaluation of a pre-pupae meal of the black soldier fly (Hermetia illucens) as fish meal substitute - growth performance and chitin degradation in juvenile turbot (Psetta maxima). Aquaculture 364-365: 345-352. https://doi.org/10.1016/j.aquaculture.2012.08.041

Krogdahl, Å., Bakke-McKellep, A.M. and Baeverfjord, G., 2003. Effects of graded levels of standard soybean meal on intestinal structure, mucosal enzyme activities, and pancreatic response in Atlantic salmon (Salmo salar L.). Aquaculture Nutrition 9(6): 361-371. https://doi.org/10.1046/j.1365-2095.2003.00264.x

Krogdahl, Å., Gajardo, K., Kortner, T.M., Penn, M., Gu, M., Berge, G.M. and Bakke, A.M., 2015. Soya saponins induce enteritis in Atlantic salmon (Salmo salar L.). Journal of Agricultural and Food Chemistry 63: 3887-3902. https://doi.org/10.1021/jf506242t

Krogdahl, Å., Penn, M., Thorsen, J., Refstie, S. and Bakke, A.M., 2010. Important antinutrients in plant feedstuffs for aquaculture: an update on recent findings regarding responses in salmonids. Aquaculture Research 41(3): 333-344. https://doi.org/10.1111/ j.1365-2109.2009.02426.x

Kumar, G., Cho, S., Sivagurunathan, P., Anburajan, P., Mahapatra, D.M., Park, J. and Pugazhendhi, A., 2018. Insights into evolutionary trends in molecular biology tool in microbial screening for biohydrogen production through dark fermentation. International Journal of Hydrogen Energy 43(43): 19885-19901. https://doi.org/10.1016/j. ijhydene.2018.09.040

Laporte, J. and Trushenski, J., 2012. Production performance, stress tolerance and intestinal integrity of sunshine bass fed increasing levels of soybean meal. Journal of Animal Physiology and Animal Nutrition 96(3): 513-526. https://doi.org/10.1111/j.14390396.2011.01174.x

Lazado, C.C. and Caipang, C.M.A., 2014. Mucosal immunity and probiotics in fish. Fish \& Shellfish Immunology 39(1): 78-89. https:// doi.org/10.1016/j.fsi.2014.04.015

Lee, H.J. and Hwang, J., 2016. The driving role of consumers' perceived credence attributes in organic food purchase decisions: a comparison of two groups of consumers. Food Quality and Preference 54: 141151. https://doi.org/10.1016/j.foodqual.2016.07.011

Li, J., Ni, J., Li, J., Wang, C., Li, X., Wu, S., Zhang, T., Yu, Y., Yan, Q., 2014. Comparative study on gastrointestinal microbiota of eight fish species with different feeding habits. Journal of Applied Microbiology 117(6): 1750-1760. https://doi.org/10.1111/jam.12663

Li, S., Ji, H., Zhang, B., Tian, J., Zhou, J. and Yu, H., 2016. Influence of black soldier fly (Hermetia illucens) larvae oil on growth performance, body composition, tissue fatty acid composition and lipid deposition in juvenile Jian carp (Cyprinus carpio var. Jian). Aquaculture 465: 43-52. https://doi.org/10.1016/j. aquaculture.2016.08.020

Li, S., Ji, H., Zhang, B., Zhou, J. and Yu, H., 2017. Defatted black soldier fly (Hermetia illucens) larvae meal in diets for juvenile Jian carp (Cyprinus carpio var. Jian): growth performance, antioxidant enzyme activities, intestine and hepatopancreas histological structure. Aquaculture 477: 62-70. https://doi.org/10.1016/j. aquaculture.2017.04.015
Li, Y., Bruni, L., Jaramillo-Torres, A., Gajardo, K., Kortner, T.M. and Krogdahl, Å., 2020a. Differential response of digesta- and mucosaassociated intestinal microbiota to dietary black soldier fly (Hermetia illucens) larvae meal in seawater phase Atlantic salmon (Salmo salar). Animal Microbiome 3: 8. https://doi.org/10.1186/s42523020-00071-3

Li, Y., Kortner, T.M., Chikwati, E.M., Belghit, I., Lock, E.J. and Krogdahl, Å., 2020b. Total replacement of fish meal with black soldier fly (Hermetia illucens) larvae meal does not compromise the gut health of Atlantic salmon (Salmo salar). Aquaculture 520: 734967. https:// doi.org/10.1016/j.aquaculture.2020.734967

Li, Y., Kortner, T.M., Chikwati, E.M., Munang'andu, H.M., Lock, E.J. and Krogdahl, Å., 2019. Gut health and vaccination response in presmolt Atlantic salmon (Salmo salar) fed black soldier fly (Hermetia illucens) larvae meal. Fish \& Shellfish Immunology 86: 1106-1113. https://doi.org/10.1016/j.fsi.2018.12.057

Liland, N.S., Biancarosa, I., Araujo, P., Biemans, D., Bruckner, C.G., Waagbø, B.E., Torstensen, E. and Lock, E.J., 2017. Modulation of nutrients composition of black soldier fly (Hermetia illucens) larvae by feeding seaweed-enriched media. PLoS ONE 12: e0183188. https://doi.org/10.1371/journal.pone.0183188

Lindholm-Lehto, P.C., Suurnäkki, S., Pulkkinen, J.T., Aalto, S.L., Tiirola, M. and Vielma, J., 2019. Effect of peracetic acid on levels of geosmin, 2-methylisoborneol, and their potential producers in a recirculating aquaculture system for rearing rainbow trout (Oncorhynchus mykiss). Aquaculture Engineering 85: 56-64. https:// doi.org/10.1016/j.aquaeng.2019.02.002

Liu, H., Guo, X., Gooneratne, R., Lai, R., Zeng, C., Zhan, F. and Wang, W., 2016. The gut microbiome and degradation enzyme activity of wild freshwater fishes influenced by their trophic levels. Scientific Reports 6: 24340. https://doi.org/10.1038/srep24340

Llewellyn, M.S., Boutin, S., Hoseinifar, S.H. and Derome, N., 2014. Teleost microbiomes: the state of the art in their characterization, manipulation and importance in aquaculture and fisheries. Frontiers in Microbiology 5: 207. https://doi.org/10.3389/fmicb.2014.00207

Lock, E.R., Arsiwalla, T. and Waagbø, R., 2016. Insect larvae meal as an alternative source of nutrients in the diet of Atlantic salmon (Salmo salar) postsmolt. Aquaculture Nutrition 22: 1202-1213. https://doi.org/10.1111/anu.12343

Lopes, I.G., Lalander, C., Vidotti, R.M. and Vinnerås, B., 2020. Using Hermetia illucens larvae to process biowaste from aquaculture production. Journal of Cleaner Production 251: 119753. https:// doi.org/10.1016/j.jclepro.2019.119753

Luo, L., Wei, H., Ai, L., Liang, X., Wu, X., Xing, W., Chen, P. and Xue, M., 2019. Effects of early long-chain n-3HUFA programming on growth, antioxidant response and lipid metabolism of Siberian sturgeon (Acipenser baerii Brandt). Aquaculture 509: 96-103. https:// doi.org/10.1016/j.aquaculture.2019.05.032

Mancini, S., Medina, I., Iaconisi, V., Gai, F., Basto, A. and Parisi, G., 2018. Impact of black soldier fly larvae meal on the chemical and nutritional characteristics of rainbow trout fillets. Animal 12(8): 1672-1681. https://doi.org/10.1017/S1751731117003421 
Marjara, I.S., Chikwati, E.M., Valen, E.C., Krogdahl, Å. and Bakke, A.M., 2012. Transcriptional regulation of IL-17A and other inflammatory markers during the development of soybean mealinduced enteropathy in the distal intestine of Atlantic salmon (Salmo salar L.). Cytokine 60(1): 186-196. https://doi.org/10.1016/j. cyto.2012.05.027

Maslowski, K.M. and MacKay, C.R., 2011. Diet, gut microbiota and immune responses. Nature Immunology 12: 5-9. https://doi. org/10.1038/ni0111-5

McAdam, P.R., Richardson, E.J. and Fitzgerald, J.R., 2014. Highthroughput sequencing for the study of bacterial pathogen biology. Current Opinion in Microbiology 19: 106-113. https:// doi.org/10.1016/j.mib.2014.06.002

McFadzen, I.R.B., Coombs, S.H. and Halliday, N.C., 1997. Histological indices of the nutritional condition of sardine, Sardina pilchardus (Walbaum) larvae off the north coast of Spain. Journal of Experimental Marine Biology and Ecology 212(2): 239-258. https:// doi.org/10.1016/S0022-0981(96)02755-4

Metzker, M.L., 2010. Sequencing technologies - the next generation. Nature Reviews Genetics 11: 31-46. https://doi.org/10.1038/nrg2626 Mokhtar, D.M., 2017. Fish histology: from cells to organs, $1^{\text {st }}$ edition. Apple Academic Press, Boca Raton, FL, USA, 264 pp. https://doi. org/10.1201/9781315205779

Mokrzycki, W. and Tatol, M., 2011. Color difference Delta E - a survey. Machine Graphics and Vision 20(4): 383-411.

Morris, P.C., Gallimore, P., Handley, J., Hide, G., Haughton, P. and Black, A., 2005. Full-fat soya for rainbow trout (Oncorhynchus mykiss) in freshwater: effects on performance, composition and flesh fatty acid profile in absence of hind-gut enteritis. Aquaculture 248(1-4): 147-161. https://doi.org/10.1016/j.aquaculture.2005.04.021

Moutinho, S., Martínez-Llorens, S., Tomás-Vidal, A., Jover-Cerdá, M., Oliva-Teles, A. and Peres, H., 2017. Meat and bone meal as partial replacement for fish meal in diets for gilthead seabream (Sparus aurata) juveniles: growth, feed efficiency, amino acid utilization, and economic efficiency. Aquaculture 468(1): 271-277. https://doi. org/10.1016/j.aquaculture.2016.10.024

Müller, A., Wolf, D. and Gutzeit, H.O., 2017. The black soldier fly, Hermetia illucens - a promising source for sustainable production of proteins, lipids and bioactive substances. Zeitschrift für Naturforsch C 72(9-10): 351-363. https://doi.org/10.1515/znc-2017-0030

Muyzer, G., 1999. DGGE/TGGE a method for identifyng genes from natural ecosystems. Current Opinion in Microbiology 2(3): 317-322. https://doi.org/10.1016/S1369-5274(99)80055-1

Nawaz, A., Bakhsh Javaid, A., Irshad, S., Hoseinifar, S.H. and Xiong, H., 2018. The functionality of prebiotics as immunostimulant: evidences from trials on terrestrial and aquatic animals. Fish \& Shellfish Immunology 76: 272-278. https://doi.org/10.1016/j.fsi.2018.03.004

Nayak, S.K., 2010. Probiotics and immunity: a fish perspective. Fish \& Shellfish Immunology 29(1): 2-14. https://doi.org/10.1016/j. fsi.2010.02.017

Naylor, R., Hindar, K., Fleming, I.A., Goldburg, R., Williams, S., Volpe, J., Whoriskey, F., Eagle, J., Kelso, D., Mangel, M., 2005. Fugitive salmon: assessing the risks of escaped fish from net-pen aquaculture. Bioscience 55(5): 427-437. https://doi.org/10.1641/00063568(2005)055[0427:FSATRO]2.0.CO;2
Nieva-Echevarría, B., Goicoechea, E., Manzanos, M.J. and Guillén, M.D., 2018. Effects of different cooking methods on the lipids and volatile components of farmed and wild European sea bass (Dicentrarchus labrax). Food Research International 103: 48-58. https://doi.org/10.1016/j.foodres.2017.10.029

Nogales-Mérida, S., Gobbi, P., Józefiak, D., Mazurkiewicz, J., Dudek, K., Rawski, M., Kierończyk, B. and Józefiak, A., 2018. Insect meals in fish nutrition. Reviews in Aquaculture 11(4): 1080-1103. https:// doi.org/10.1111/raq.12281

Notarstefano, V., Gioacchini, G., Byrne, H.J., Zacà, C., Sereni, E., Vaccari, L., Borini, A., Carnevali, O. and Giorgini, E., 2019. Vibrational characterization of granulosa cells from patients affected by unilateral ovarian endometriosis: new insights from infrared and Raman microspectroscopy. Spectrochimica Acta Part A: Molecular and Biomolecular Spectroscopy 212: 206-214. https:// doi.org/10.1016/j.saa.2018.12.054

Notarstefano, V., Sabbatini, S., Conti, C., Pisani, M., Astolfi, P., Pro, C., Rubini, C., Vaccari, L. and Giorgini, E., 2020. Investigation of human pancreatic cancer tissues by Fourier transform infrared hyperspectral imaging. Journal of Biophotonics 13(4): e201960071. https://doi.org/10.1002/jbio.201960071

Novriadi, R., Rhodes, M., Powell, M., Hanson, T. and Davis, D.A., 2018. Effects of soybean meal replacement with fermented soybean meal on growth, serum biochemistry and morphological condition of liver and distal intestine of Florida pompano Trachinotus carolinus. Aquaculture Nutrition 24(3): 1066-1075. https://doi.org/10.1111/ anu. 12645

O'Connell, C.P., 1976. Histological criteria for diagnosing the starving condition in early post yolk sac larvae of the northern anchovy, Engraulis mordax Girard. Journal of Experimental Marine Biology and Ecology 25(3): 285-312. https://doi.org/10.1016/00220981(76)90130-1

Oliva-Teles, A., Enes, P. and Peres, H., 2015. Replacing fishmeal and fish oil in industrial aquafeeds for carnivorous fish. Feed and feeding practices in aquaculture. Woodhead Publishing, Cambridge, UK, 432 pp. https://doi.org/10.1016/b978-0-08-100506-4.00008-8

Olivotto, I., Di Stefano, M., Rosetti, S., Cossignani, L., Pugnaloni, A., Giantomassi, F. and Carnevali, O., 2011. Live prey enrichment, with particular emphasis on HUFAs, as limiting factor in false percula clownfish (Amphiprion ocellaris, Pomacentridae) larval development and metamorphosis: molecular and biochemical implications. Comparative Biochemistry and Physiology Part A: Molecular \& Integrative Physiology 159(3): 207-218. https://doi. org/10.1016/j.cbpa.2011.02.004

Olivotto, I., Mosconi, G., Maradonna, F., Cardinali, M. and Carnevali, O., 2002. Diplodus sargus interrenal-pituitary response: chemical communication in stressed fish. General and Comparative Endocrinology 127(1): 66-70. https://doi.org/10.1016/S00166480(02)00024-2

Olsen, R.E., Suontama, J., Langmyhr, E., Mundheim, H., Ringo, E., Melle, W., Malde, M.K. and Hemre, G.I., 2006. The replacement of fish meal with Antarctic krill, Euphausia superba in diets for Atlantic salmon, Salmo salar. Aquaculture Nutrition 12: 280-290. https://doi.org/10.1111/j.1365-2095.2006.00400.x 
Osimani, A., Milanović, V., Roncolini, A., Riolo, P., Ruschioni, S., Isidoro, N., Loreto, N., Franciosi, E., Tuohy, K., Olivotto, I., Zarantoniello, M., Cardinali, F., Garofalo, C., Aquilanti, L. and Clementi, F., 2019. Hermetia illucens in diets for zebrafish (Danio rerio): A study of bacterial diversity by using PCR-DGGE and metagenomic sequencing. PLoS ONE 14(12): e0225956. https:// doi.org/10.1371/journal.pone.0225956

Panagiotaki, P. and Malandrakis, E.E., 2019. Aquatic environment and fish welfare in aquaculture. Reference module in earth systems and environmental sciences. Encyclopedia of Environmental Health, $2^{\text {nd }}$ edition. Elsevier, New York, NY, USA, 4884 pp. https://doi. org/10.1016/B978-0-12-409548-9.10959-5

Papatryphon, E. and Soares, J.H., 2001. Optimizing the levels of feeding stimulants for use in high-fish meal and plant feedstuff-based diets for striped bass, Morone saxatilis. Aquaculture 202(3-4): 279-288. https://doi.org/10.1016/S0044-8486(01)00778-5

Parodi, A., De Boer, I.J.M., Gerrits, W.J.J., Van Loon, J.J.A., Heetkamp, M.J.W., Van Schelt, J., Bolhuis, J.E. and Van Zanten, H.H.E., 2020. Bioconversion efficiencies, greenhouse gas and ammonia emissions during black soldier fly rearing - a mass balance approach. Journal of Cleaner Production 271: 122488. https://doi.org/10.1016/j. jclepro.2020.122488

Penn, M.H., Bendiksen, E.A., Campbell, P. and Krogdahl, A.S., 2011. High level of dietary pea protein concentrate induces enteropathy in Atlantic salmon (Salmo salar L.). Aquaculture 310: 267-273. https://doi.org/10.1016/j.aquaculture.2010.10.040

Peterson, L.W. and Artis, D., 2014. Intestinal epithelial cells: regulators of barrier function and immune homeostasis. Nature Reviews Immunology 14: 141-153. https://doi.org/10.1038/nri3608

Picard, B., Gagaoua, M. and Hollung, K., 2017. Gene and protein expression as a tool to explain/predict meat (and fish) quality. New aspects of meat quality: from genes to ethics. Woodhead Publishing, Cambridge, UK, 744 pp. https://doi.org/10.1016/b9780-08-100593-4.00013-8

Piccinetti, C.C., Donati, M., Radaelli, G., Caporale, G., Mosconi, G., Palermo, F., Cossignani, L., Salvatori, R., Lopez, R.P. and Olivotto, I., 2015. The effects of starving and feeding on Dover sole (Solea solea, Soleidae, Linnaeus, 1758) stress response and early larval development. Aquaculture Research 46: 2512-2526. https://doi. org/10.1111/are.12410

Piccinetti, C.C., Grasso, L., Maradonna, F., Radaelli, G., Ballarin, C., Chemello, G., Evjemo, J.O., Carnevali, O. and Olivotto, I., 2017. Growth and stress factors in ballan wrasse (Labrus bergylta) larval development. Aquaculture Research 48(5): 2567-2580. https://doi. org/10.1111/are.13093

Pimentel, A.C., Montali, A., Bruno, D. and Tettamanti, G., 2017. Metabolic adjustment of the larval fat body in Hermetia illucens to dietary conditions. Journal of Asia-Pacific Entomology 20(4): 1307-1313. https://doi.org/10.1016/j.aspen.2017.09.017

Psofakis, P., Karapanagiotidis, I.T., Malandrakis, E.E., Golomazou, E., Exadactylos, A. and Mente, E., 2020. Effect of fishmeal replacement by hydrolyzed feather meal on growth performance, proximate composition, digestive enzyme activity, haematological parameters and growth-related gene expression of gilthead seabream (Sparus aurata). Aquaculture 521: 735006. https://doi.org/10.1016/j. aquaculture.2020.735006
Purushothaman, K., Lau, D., Saju, J.M., Syed Musthaq, S.K., Lunny, D.P., Vij, S. and Orbán, L., 2016. Morpho-histological characterisation of the alimentary canal of an important food fish, Asian seabass (Lates calcarifer). PeerJ Life \& Environment 4: e2377. https://doi. org/10.7717/peerj.2377

Qin, C., Zhang, Y., Liu, W., Xu, L., Yang, Y. and Zhou, Z., 2014. Effects of chito-oligosaccharides supplementation on growth performance, intestinal cytokine expression, autochthonous gut bacteria and disease resistance in hybrid tilapia Oreochromis niloticus $q \times$ Oreochromis aureus $\widehat{\jmath}$. Fish \& Shellfish Immunology 40(1): 267274. https://doi.org/10.1016/j.fsi.2014.07.010

Randazzo, B., Zarantoniello, M., Cardinaletti, G., Cerri, R., Giorgini, E., Belloni, A., Contò, M., Tibaldi, E. and Olivotto, I., 2021a. Hermetia illucens and poultry by-product meals as alternatives to plant protein sources in gilthead seabream (Sparus aurata) diet: a multidisciplinary study on fish gut status. Animals 11: 677. https:// doi.org/10.3390/ani11030677

Randazzo, B., Zarantoniello, M., Gioacchini, G., Cardinaletti, G., Belloni, A., Giorgini, E., Faccenda, F., Cerri, R., Tibaldi, E. and Olivotto, I., 2021b. Physiological response of rainbow trout (Oncorhynchus mykiss) to graded levels of Hermetia illucens or poultry by-product meals as single or combined substitute ingredients to dietary plant proteins. Aquaculture 538: 736550. https://doi.org/10.1016/j.aquaculture.2021.736550

Randazzo, B., Zarantoniello, M., Gioacchini, G., Giorgini, E., Truzzi, C., Notarstefano, V., Cardinaletti, G., Huyen, K.T., Carnevali, O. and Olivotto, I., 2020a. Can insect-based diets affect zebrafish (Danio rerio) reproduction? A multidisciplinary study. Zebrafish 17(5): 287-304. https://doi.org/10.1089/zeb.2020.1891

Randazzo, B., Zarantoniello, M., Tibaldi, E., Cardinaletti, G., Giorgini, E., Lunelli, F., Olivotto, I., 2020b. A multidisciplinary approach to investigate biological effects on intestine phisiology and appetite stimulus in rainbow trout Onchorhincus mykiss fed diets with graded levels of insect meal and poultry by-product meal. In: Aquaculture America 2020. February 9-12, 2020. World Aquaculture Society, Honolulu, HI, USA. Available at: https://www.was.org/Meeting/ code/AA2020

Raskovic, B., Stankovic, M., Markovic, Z. and Poleksic, V., 2011. Histological methods in the assessment of different feed effects on liver and intestine of fish. Journal of Agricultural Science, Belgrade 56(11): 87-10. https://doi.org/10.2298/jas1101087r

Ray, A.K. and Ringø, E., 2014. The gastrointestinal tract of fish. Aquaculture nutrition: gut health, probiotics and prebiotics, $1^{\text {st }}$ edition. John Wiley \& Sons, Hoboken, NJ, USA, 465 pp. https:// doi.org/10.1002/9781118897263.ch1

Razin, S., 2006. The genus mycoplasma and related genera (class mollicutes). The prokaryotes. Springer, New York, NY, USA, 1186 pp. https://doi.org/10.1007/0-387-30744-3_29

Renna, M., Schiavone, A., Gai, F., Dabbou, S., Lussiana, C., Malfatto, V., Prearo, M., Capucchio, M.T., Biasato, I., Biasibetti, E., De Marco, M., Brugiapaglia, A., Zoccarato, I. and Gasco, L., 2017. Evaluation of the suitability of a partially defatted black soldier fly (Hermetia illucens L.) larvae meal as ingredient for rainbow trout (Oncorhynchus mykiss Walbaum) diets. Journal of Animal Science and Biotechnology 8: 57. https://doi.org/10.1186/s40104-017-0191-3 
Ribas, L. and Piferrer, F., 2014. The zebrafish (Danio rerio) as a model organism, with emphasis on applications for finfish aquaculture research. Reviews in Aquaculture 6(4): 209-240. https://doi. org/10.1111/raq.12041

Rimoldi, S., Finzi, G., Ceccotti, C., Girardello, R., Grimaldi, A., Ascione, C. and Terova, G., 2016. Butyrate and taurine exert a mitigating effect on the inflamed distal intestine of European sea bass fed with a high percentage of soybean meal. Fisheries and Aquatic Sciences 19: 40. https://doi.org/10.1186/s41240-016-0041-9

Rimoldi, S., Gini, E., Iannini, F., Gasco, L. and Terova, G., 2019. The effects of dietary insect meal from Hermetia illucens prepupae on autochthonous gut microbiota of rainbow trout (Oncorhynchus mykiss). Animals 9(4): 143. https://doi.org/10.3390/ani9040143

Ringø, E., Zhou, Z., Olsen, R.E. and Song, S.K., 2012. Use of chitin and krill in aquaculture - the effect on gut microbiota and the immune system: a review. Aquaculture Nutrition 18(2): 117-131. https://doi. org/10.1111/j.1365-2095.2011.00919.x

Ringø, E., Zhou, Z., Vecino, J.L.G., Wadsworth, S., Romero, J., Krogdahl, Olsen, R.E., Dimitroglou, A., Foey, A., Davies, S., Owen, M., Lauzon, H.L., Martinsen, L.L., De Schryver, P., Bossier, P., Sperstad, S. and Merrifield, D.L., 2016. Effect of dietary components on the gut microbiota of aquatic animals. A never-ending story? Aquaculture Nutrition 22(2): 219-282. https://doi.org/10.1111/anu.12346

Robaina, L., Izquierdo, M.S., Moyano, F.J., Socorro, J., Vergara, J.M., Montero, D. and Fernández-Palacios, H., 1995. Soybean and lupin seed meals as protein sources in diets for gilthead seabream (Sparus aurata): nutritional and histological implications. Aquaculture 130(2-3): 219-233. https://doi.org/10.1016/0044-8486(94)00225-D

Ruxton, C.H.S., Reed, S.C., Simpson, M.J.A. and Millington, K.J., 2004. The health benefits of omega-3 polyunsaturated fatty acids: a review of the evidence. Journal of Human Nutrition and Dietetics 17(5): 449-459. https://doi.org/10.1111/j.1365-277X.2004.00552.x

Sabbagh, M., Schiavone, R., Brizzi, G., Sicuro, B., Zilli, L. and Vilella, S., 2019. Poultry by-product meal as an alternative to fish meal in the juvenile gilthead seabream (Sparus aurata) diet. Aquaculture 511: 734220. https://doi.org/10.1016/j.aquaculture.2019.734220

Sadoul, B. and Vijayan, M.M., 2016. Stress and growth. Fish Physiology 35: 167-205. https://doi.org/10.1016/B978-0-12-802728-8.00005-9

Salomone, R., Saija, G., Mondello, G., Giannetto, A., Fasulo, S. and Savastano, D., 2017. Environmental impact of food waste bioconversion by insects: application of life cycle assessment to process using Hermetia illucens. Journal of Cleaner Production 140(2): 890-905. https://doi.org/10.1016/j.jclepro.2016.06.154.

Santigosa, E., García-Meilán, I., Valentin, J.M., Pérez-Sánchez, J., Médale, F., Kaushik, S. and Gallardo, M.A., 2011. Modifications of intestinal nutrient absorption in response to dietary fish meal replacement by plant protein sources in sea bream (Sparus aurata) and rainbow trout (Onchorynchus mykiss). Aquaculture 317: 146154. https://doi.org/10.1016/j.aquaculture.2011.04.026

Sealey, W.M., Gaylord, T.G., Barrows, F.T., Tomberlin, J.K., McGuire, M.A., Ross, C., St-Hilaire, S., 2011. Sensory analysis of rainbow trout, Oncorhynchus mykiss, fed enriched black soldier fly prepupae, Hermetia illucens. Journal of the World Aquaculture Society 42(1): 34-45. https://doi.org/10.1111/j.1749-7345.2010.00441.x
Secci, G., Mancini, S., Iaconisi, V., Gasco, L., Basto, A. and Parisi, G., 2019. Can the inclusion of black soldier fly (Hermetia illucens) in diet affect the flesh quality/nutritional traits of rainbow trout (Oncorhynchus mykiss) after freezing and cooking? International Journal of Food Sciences and Nutrition 70(2): 161-171. https://doi. org/10.1080/09637486.2018.1489529

Seierstad, S.L., Haugland, Ø., Larsen, S., Waagbø, R. and Evensen, Ø., 2009. Pro-inflammatory cytokine expression and respiratory burst activity following replacement of fish oil with rapeseed oil in the feed for Atlantic salmon (Salmo salar L.). Aquaculture 289: 212-218. https://doi.org/10.1016/j.aquaculture.2008.12.004

Sekirov, I., Russell, S.L., Caetano M Antunes, L. and Finlay, B.B., 2010. Gut microbiota in health and disease. Physiological Reviews 90(3): 859-904. https://doi.org/10.1152/physrev.00045.2009

Sharma, G. and Bala, R., 2002. Digital color imaging handbook, $1^{\text {st }}$ edition. CRC Press, London, UK, 840 pp.

Silva, P.F., McGurk, C., Knudsen, D.L., Adams, A., Thompson, K.D. and Bron, J.E., 2015. Histological evaluation of soya bean-induced enteritis in Atlantic salmon (Salmo salar L.): Quantitative image analysis vs. semi-quantitative visual scoring. Aquaculture 445: 4256. https://doi.org/10.1016/j.aquaculture.2015.04.002

Skrivanová, E., Marounek, M., Benda, V. and Brezina, P., 2007. Susceptibility of Escherichia coli, Salmonella sp. and Clostridium perfringens to organic acids and monolaurin. Veterinarni Medicina 51: 81-88. https://doi.org/10.17221/5524-VETMED

Skřivanová, E., Marounek, M., Dlouhá, G. and Kaňka, J., 2005. Susceptibility of Clostridium perfringens to C2-C18 fatty acids. Letters in Applied Microbiology 41(1): 77-81. https://doi. org/10.1111/j.1472-765X.2005.01709.x

Smetana, S., Schmitt, E. and Mathys, A., 2019. Sustainable use of Hermetia illucens insect biomass for feed and food: attributional and consequential life cycle assessment. Resources, Conservation and Recycling 144: 285-296. https://doi.org/10.1016/j.resconrec. 2019.01.042

Spranghers, T., Michiels, J., Vrancx, J., Ovyn, A., Eeckhout, M., De Clercq, P. and De Smet, S., 2018. Gut antimicrobial effects and nutritional value of black soldier fly (Hermetia illucens L.) prepupae for weaned piglets. Animal Feed Sciences and Technology 235: 3342. https://doi.org/10.1016/j.anifeedsci.2017.08.012

Spranghers, T., Ottoboni, M., Klootwijk, C., Ovyn, A., Deboosere, S., De Meulenaer, B., Michiels, J., Eeckhout, M., De Clercq, P. and De Smet, S., 2017. Nutritional composition of black soldier fly (Hermetia illucens) prepupae reared on different organic waste substrates. Journal of the Science of Food and Agriculture 97(8): 2594-2600. https://doi.org/10.1002/jsfa.8081

Stadtlander, T., Stamer, A., Buser, A., Wohlfahrt, J., Leiber, F. and Sandrock, C., 2017. Hermetia illucens meal as fish meal replacement for rainbow trout on farm. Journal of Insects as Food and Feed 3: 165-175. https://doi.org/10.3920/JIFF2016.0056

St-Hilaire, S., Sheppard, C., Tomberlin, J.K., Irving, S., Newton, L., McGuire, M.A., Mosley, E.E., Hardy, R.W. and Sealey, W., 2007. Fly prepupae as a feedstuff for rainbow trout, Oncorhynchus mykiss. Journal of World Aquaculture Society 38(1): 59-67. https://doi. org/10.1111/j.1749-7345.2006.00073.x 
Swatson, H.K., Gous, R., Iji, P.A. and Zarrinkalam, R., 2002. Effect of dietary protein level, amino acid balance and feeding level on growth, gastrointestinal tract, and mucosal structure of the small intestine in broiler chickens. Animal Research 51(6): 501-515. https://doi.org/10.1051/animres:2002038

Swinscoe, I., Oliver, D.M., Gilburn, A.S., Lunestad, B., Lock, E.J., Ørnsrud, R. and Quilliam, R.S., 2019. Seaweed-fed black soldier fly (Hermetia illucens) larvae as feed for salmon aquaculture: assessing the risks of pathogen transfer. Journal of Insects as Food Feed 5: 15-27. https://doi.org/10.3920/JIFF2017.0067

Tacon, A.G.J. and Metian, M., 2015. Feed matters: satisfying the feed demand of aquaculture. Reviews in Fisheries Science \& Aquaculture 23(1): 1-10. https://doi.org/10.1080/23308249.2014.987209

Talari, A.C.S., Martinez, M.A.G., Movasaghi, Z., Rehman, S. and Rehman, I.U., 2017. Advances in Fourier transform infrared (FTIR) spectroscopy of biological tissues. Applied Spectroscopy Reviews 52(5): 456-506. https://doi.org/10.1080/05704928.201 6.1230863

Terova, G., Díaz, N., Rimoldi, S., Ceccotti, C., Gliozheni, E., Piferrer, F., 2016. Effects of sodium butyrate treatment on histone modifications and the expression of genes related to epigenetic regulatory mechanisms and immune response in European sea bass (Dicentrarchus Labrax) fed a plant-based diet. PLoS ONE 11: e0160332. https://doi.org/10.1371/journal.pone.0160332

Terova, G., Rimoldi, S., Ascione, C., Gini, E., Ceccotti, C. and Gasco, L., 2019. Rainbow trout (Oncorhynchus mykiss) gut microbiota is modulated by insect meal from Hermetia illucens prepupae in the diet. Reviews in Fish Biology and Fisheries 29: 465-486. https://doi. org/10.1007/s11160-019-09558-y

Tocher, D.R., 2010. Fatty acid requirements in ontogeny of marine and freshwater fish. Aquaculture Research 41: 717-732. https:// doi.org/10.1111/j.1365-2109.2008.02150.x

Truzzi, C., Giorgini, E., Annibaldi, A., Antonucci, M., Illuminati, S., Scarponi, G., Riolo, P., Isidoro, N., Conti, C., Zarantoniello, M., Cipriani, R. and Olivotto, I., 2020. Fatty acids profile of black soldier fly (Hermetia illucens): influence of feeding substrate based on coffee-waste silverskin enriched with microalgae. Animal Feed Science and Technology 259: 114309. https://doi.org/10.1016/j. anifeedsci.2019.114309

Udayangani, R.M.C., Dananjaya, S.H.S., Nikapitiya, C., Heo, G.J., Lee, J. and De Zoysa, M., 2017. Metagenomics analysis of gut microbiota and immune modulation in zebrafish (Danio rerio) fed chitosan silver nanocomposites. Fish \& Shellfish Immunology 66: 173-184. https://doi.org/10.1016/j.fsi.2017.05.018

Uran, P.A., Schrama, J.W., Rombout, J.H.W.M., Obach, A., Jensen, L., Koppe, W. and Verreth, J.A.J., 2008. Soybean meal-induced enteritis in Atlantic salmon (Salmo salar L.) at different temperatures. Aquaculture Nutrition 14(4): 324-330. https://doi.org/10.1111/ j.1365-2095.2007.00534.x

Valasek, M.A. and Repa, J.J., 2005. The power of real-time PCR. American Journal of Physiology 29(3): 151-159. https://doi. org/10.1152/advan.00019.2005
Van Huis, C.L., Van Itterbeeck, J., Klunder, H., Mertens, E., Halloran, A., Muir, G. and Vantomme, P., 2013. Edible insects. Future prospects for food and feed security. FAO Forestry Paper 171. FAO, Rome, Italy, 18 pp. Available at: http://www.fao.org/3/i3253e/ i3253e00.pdf

Vargas, A., Randazzo, B., Riolo, P., Truzzi, C., Gioacchini, G., Giorgini, E., Loreto, N., Ruschioni, S., Zarantoniello, M., Antonucci, M., Polverini, S., Cardinaletti, G., Sabbatini, S., Tulli, F. and Olivotto, I., 2018. Rearing zebrafish on black soldier fly (Hermetia illucens): biometric, histological, spectroscopic, biochemical, and molecular implications. Zebrafish 15: 404-419. https://doi.org/10.1089/zeb.2017.1559

Vargas-Abúndez, A.J., Randazzo, B., Foddai, M., Sanchini, L., Truzzi, C., Giorgini, E., Gasco, L. and Olivotto, I., 2019. Insect meal based diets for clownfish: biometric, histological, spectroscopic, biochemical and molecular implications. Aquaculture 498: 1-11. https://doi.org/10.1016/j.aquaculture.2018.08.018

Voorhees, J.M., Barnes, M.E., Chipps, S.R. and Brown, M.L., 2019. Bioprocessed soybean meal replacement of fish meal in rainbow trout (Oncorhynchus mykiss) diets. Cogent Food \& Agriculture Animal Husbandry \& Veterinary Sciences 5(1): 1579482. https:// doi.org/10.1080/23311932.2019.1579482

Wang, A.R., Ran, C., Ringø, E. and Zhou, Z.G., 2018. Progress in fish gastrointestinal microbiota research. Reviews in Aquaculture 10(3): 626-640. https://doi.org/10.1111/raq.12191

Wang, G., Peng, K., Hu, J., Yi, C., Chen, X., Wu, H. and Huang, Y., 2019. Evaluation of defatted black soldier fly (Hermetia illucens L.) larvae meal as an alternative protein ingredient for juvenile Japanese seabass (Lateolabrax japonicus) diets. Aquaculture 507: 144-154. https://doi.org/10.1016/j.aquaculture.2019.04.023

Winther, U., Skontorp Hognes, E., Jafarzadeh, S. and Ziegler, F., 2020. Greenhouse gas emissions of Norwegian seafood products in 2017. SINTEF Report, SINTEF Ocean AS, Trondheim, Norway, 116 pp. Available at: https://www.sintef.no/contentassets/25338e561f1a427 0a59ce25bcbc926a2/report-carbon-footprint-norwegian-seafoodproducts-2017_final_040620.pdf/

Wong, M.L. and Medrano, J.F., 2005. Real-time PCR for mRNA quantitation. Biotechniques 39(1): 75-85. https://doi.org/10.2144/ 05391RV01

Wong, S., Waldrop, T., Summerfelt, S., Davidson, J., Barrows, F., Kenney, B.B., Welch, T., Wiens, G.D., Snekvi, K., Rawls, J.F. and Good, C., 2013. Aquacultured rainbow trout (Oncorhynchus mykiss) possess a large core intestinal microbiota that is resistant to variation in diet and rearing density. Applied Environmental Microbiology 79: 4974-4984. https://doi.org/10.1128/AEM.00924-13

Yasothai, R., 2016. Antinutritional factors in soybean meal and its deactivation. International Journal of Science, Environment \& Technology 5(6): 3793-3797.

Zarantoniello, M., Bruni, L., Randazzo, B., Vargas, A., Gioacchini, G., Truzzi, C., Annibaldi, A., Riolo, P., Parisi, G., Cardinaletti, G., Tulli, F. and Olivotto, I., 2018. Partial dietary inclusion of Hermetia illucens (black soldier fly) full-fat prepupae in zebrafish feed: biometric, histological, biochemical, and molecular implications. Zebrafish 15: 519-532. https://doi.org/10.1089/zeb.2018.1596 
Zarantoniello, M., Randazzo, B., Gioacchini, G., Truzzi, C., Giorgini, E., Riolo, P., Gioia, G., Bertolucci, C., Osimani, A., Cardinaletti, G., Lucon-Xiccato, T., Milanović, V., Annibaldi, A., Tulli, F., Notarstefano, V., Ruschioni, S., Clementi, F. and Olivotto, I., 2020a. Zebrafish (Danio rerio) physiological and behavioural responses to insect-based diets: a multidisciplinary approach. Scientific Reports 10: 10648. https://doi.org/10.1038/s41598-020-67740-w

Zarantoniello, M., Randazzo, B., Nozzi, V., Truzzi, C., Giorgini, E., Cardinaletti, G., Freddi, L., Ratti, S., Girolametti, F., Osimani, A., Notarstefano, V., Milanović, V., Riolo, P., Isidoro, N., Tulli, F., Gioacchini, G. and Olivotto, I., 2021. Physiological responses of Siberian sturgeon (Acipenser baerii) juveniles fed on full-fat insectbased diet in an aquaponic system. Scientific Reports 11: 1057. https://doi.org/10.1038/s41598-020-80379-x

Zarantoniello, M., Randazzo, B., Truzzi, C., Giorgini, E., Marcellucci, C., Vargas-Abúndez, J.A., Zimbelli, A., Annibaldi, A., Parisi, G., Tulli, F., Riolo, P. and Olivotto, I., 2019. A six-months study on black soldier fly (Hermetia illucens) based diets in zebrafish. Scientific Reports 9: 8598. https://doi.org/10.1038/s41598-019-45172-5
Zarantoniello, M., Zimbelli, A., Randazzo, B., Compagni, M.D., Truzzi, C., Antonucci, M., Riolo, P., Loreto, N., Osimani, A., Milanović, V., Giorgini, E., Cardinaletti, G., Tulli, F., Cipriani, R., Gioacchini, G. and Olivotto, I., 2020b. Black soldier fly (Hermetia illucens) reared on roasted coffee by-product and Schizochytrium sp. as a sustainable terrestrial ingredient for aquafeeds production. Aquaculture 518: 734659. https://doi.org/10.1016/j.aquaculture.2019.734659

Zhang, H., Ran, C., Teame, T., Ding, Q., Hoseinifar, S.H., Xie, M., Zhang, Z., Yang, Y., Olsen, R.E., Gatlin, D.M., Ringø, E., Duan, M. and Zhou, Z., 2020. Research progress on gut health of farmers teleost fish: a viewpoint concerning the intestinal mucosal barrier and the impact of its damage. Reviews in Fish Biology and Fisheries 30: 569-586. https://doi.org/10.1007/s11160-020-09614-y

Zhang, J.-X., Guo, L.-Y., Feng, L., Jiang, W.-D., Kuang, S.-Y., Liu, Y., Hu, K., Jiang, J., Li, S.-H., Tang, L. and Zhou, X.-Q., 2013. Soybean $\beta$-conglycinin induces inflammation and oxidation and causes dysfunction of intestinal digestion and absorption in fish. PLoS ONE 8: e58115. https://doi.org/10.1371/journal.pone.0058115 
